\title{
Household Poverty in Egypt: Poverty Profile, Econometric Modeling and Policy Simulations
}

Serageldin Initiative for Multi-disciplinary Advanced Research

$$
\text { SIMAR }
$$

Bibliotheca Alexandrina

Shereen Nosier, Reham Salah, Mohamed Mahrous 


\begin{abstract}
Recognizing and understanding the roots of poverty, its elements and determinants in Egypt is vital to coming up with policy recommendations that help eradicate poverty and ameliorate welfare. As a developing country, Egypt has been suffering from increasing poverty rates since year 2000. In this study, the three most recent Egyptian Households Income, Expenditure and Consumption Surveys conducted by the Central Agency for Public Mobilization and Statistics for the years 2011, 2013 and 2015 are utilized to analyze and model the determinants of poverty in Egypt. A comprehensive poverty profile is constructed for the three years, as well as a comparison for the changes that have occurred over time on the national, rural and urban levels. Some determinants were selected as the most important factors affecting poverty, such as: demographic characteristics, employment status and educational attainment. Additionally, two econometric techniques are employed to model the different factors affecting households' consumption as well as probability of falling in poverty in Egypt; namely, Fixed Effects Regression and Logistic Regression. The results of the poverty profile, as well as both models, illustrate that the main variables which help reduce poverty are: having low family size, high number of earners and better educational attainment. On the other hand, factors that worsen poverty status of households are working in agriculture and construction sectors, depending on pension as the main source of income in addition to having high dependency ratio. Furthermore, poverty simulation analyses are conducted to assess the effect of changes in the levels of determinants of poverty on probability of being poor to show the possible consequences and effects of potential poverty lessening policies and plans.
\end{abstract}




\section{Table of Contents}

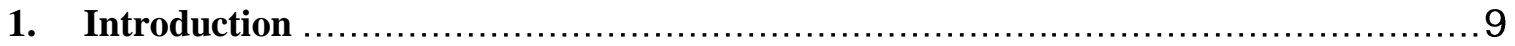

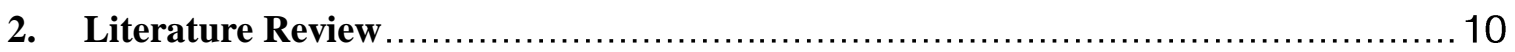

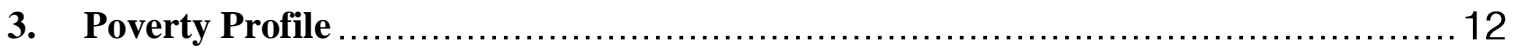

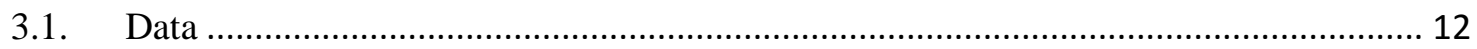

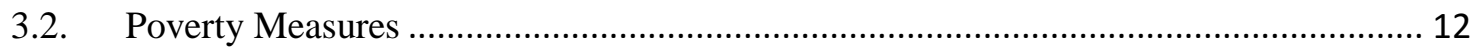

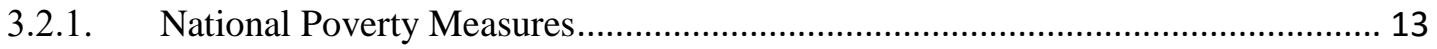

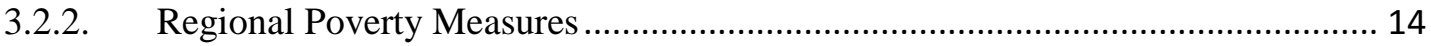

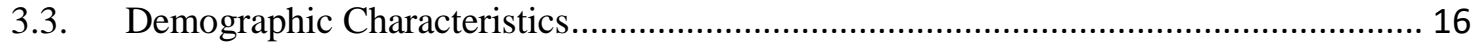

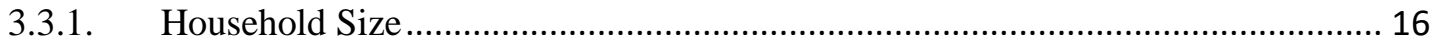

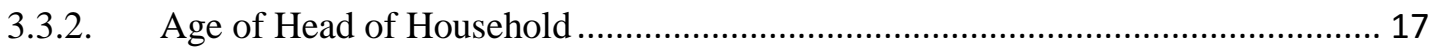

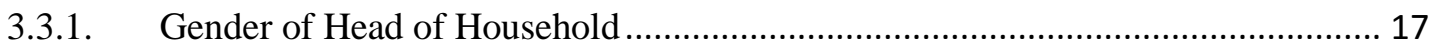

3.3.2. Marital Status of Head of Household .................................................................... 18

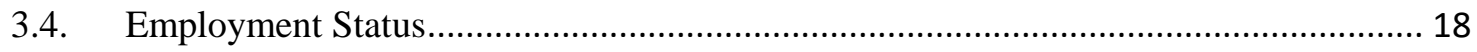

3.4.1. Status of Employment of Head of Household .................................................... 18

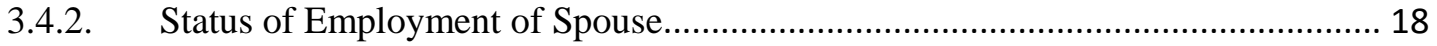

3.4.1. Sector of Employment of Head of Household...................................................... 19

3.4.1. Industry of Employment of Head of Household ................................................ 19

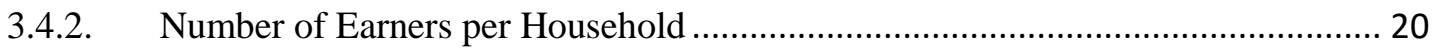

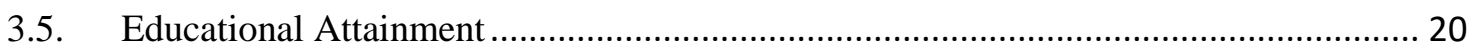

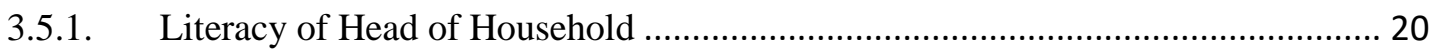

3.5.1. Educational Level of Head of Household......................................................... 20

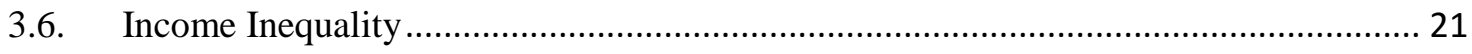

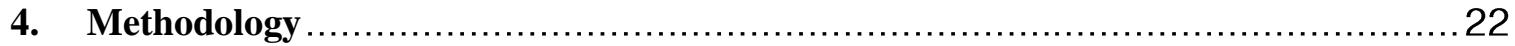

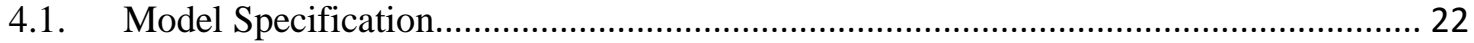

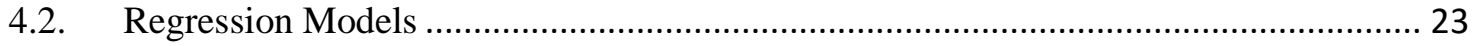

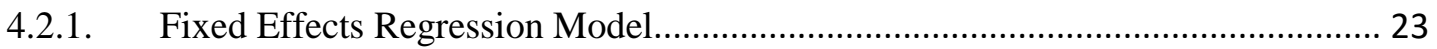

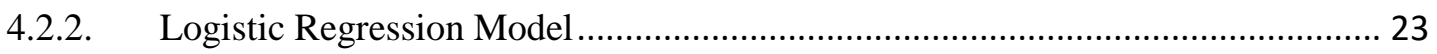

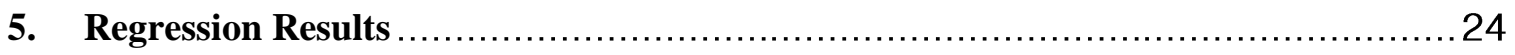

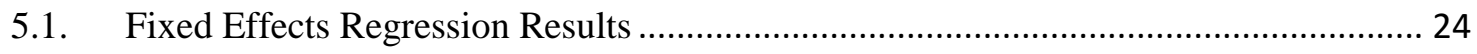

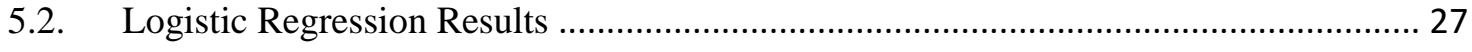

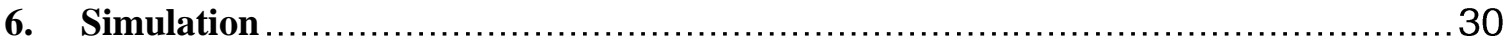




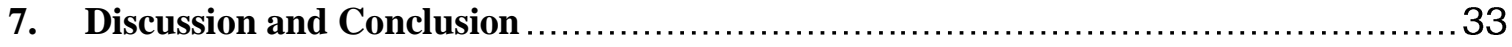

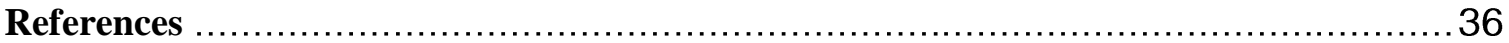

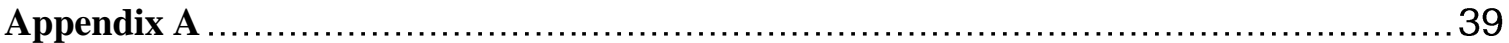

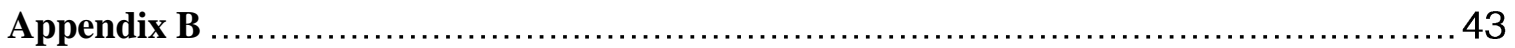

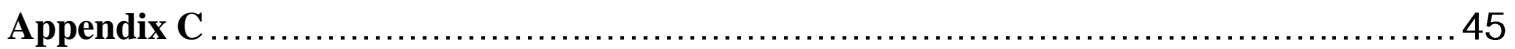

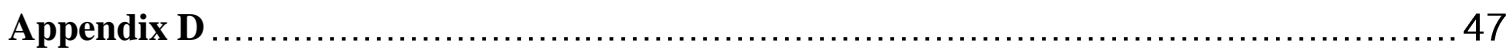




\section{List of Figures}

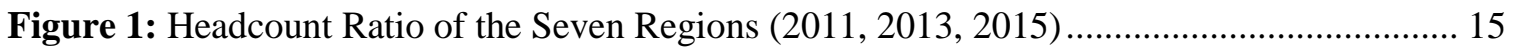

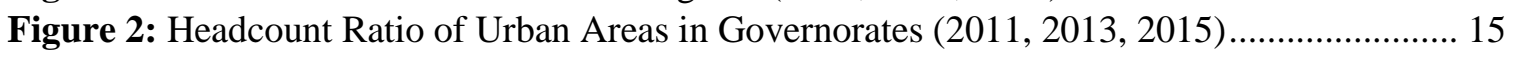

Figure 3: Headcount Ratio of Rural Areas in Governorates (2011, 2013, 2015) ....................... 16

Figure 4: Headcount Ratio of Households Based on Family Size in 2015 ............................... 16

Figure 5: Headcount Ratio of Households Based on Gender of Head of Household in 2015 ..... 17

Figure 6: Headcount Ratio of Households Based on Head's Employment Status in 2015 ......... 18

Figure 7: Headcount Ratio of Households Based on Head's Employment Industry in 2015 ...... 19

Figure 8: Headcount Ratio of Households Based on Head's Educational Level in 2015 ........... 21

Figure 9: Inequality Measures for Rural and Urban areas (2011, 2013, 2015) ......................... 21

Figure 10: The Predicted Effect of Family Size on Poverty in Egypt ....................................... 30

Figure 11: The Predicted Effect of Working Industry on Poverty in Egypt............................... 31

Figure 12: The Predicted Effect of Education on the Poverty in Egypt ..................................... 32

\section{List of Tables}

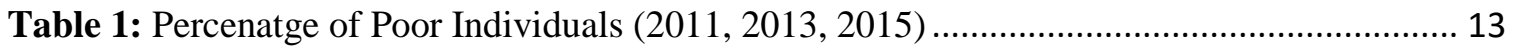

Table 2: Poverty Measurements by Household $(2011,2013,2015)$......................................... 14

Table 3: Overall Poverty Measurements for the Seven Regions $(2011,2013,2015)$.................. 14

Table 4: Fixed Effects Regression Results $(2015,2013,2011)$................................................ 25

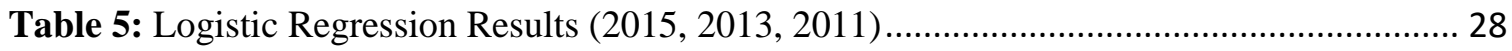

\section{Appendix A}

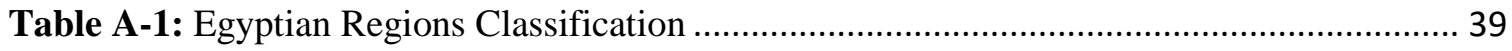

Table A-2: Poverty Measurements by Household Size (2011, 2013, 2015) .............................. 39

Table A-3: Poverty Measurements by Age of Head of Household (2011, 2013, 2015).............. 39

Table A-4: Poverty Measurements by Gender of Head of Household $(2011,2013,2015)$......... 40

Table A-5: Poverty Measurements by Marital Status of Head of Household (2011, 2013, 2015)40

Table A-6: Poverty Measurements by Status of Employment of Head of Household (2011, 2013, 2015). 40

Table A-7: Poverty Measurements by Status of Employment of Spouse $(2011,2013,2015) \ldots . . .41$ Table A-8: Poverty Measurements by Sector of Employment of Head of Household (2011, 2013, 2015) 41

Table A-9: Poverty Measurements by Number of Earners per Household $(2011,2013,2015) \ldots 41$

Table A-10: Poverty Measurements by Literacy of Head of Household $(2011,2013,2015) \ldots . . .42$

Table A-11: Poverty Measurements by Educational Level of Head of Household (2011, 2013, 2015). 


\section{Appendix B}

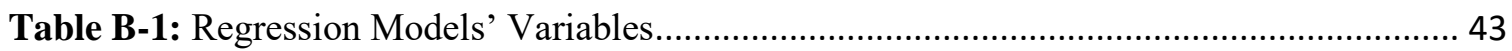




\section{Appendix C}

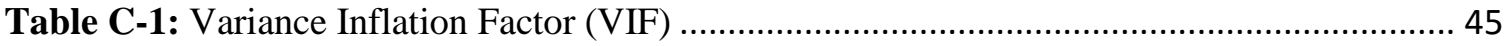

Table C-2: Breusch-Pagan/Cook-Weisberg Test for Heteroscedasticity ................................... 46

\section{Appendix D}

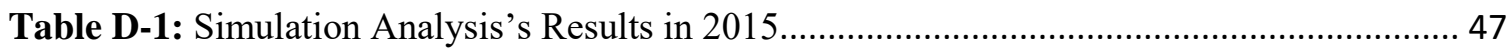




\section{List of Abbreviations}

CAPMAS Central Agency for Public Mobilization and Statistics

CDF Cumulative Distribution Function

ERF Economic Research Forum

FE $\quad$ Fixed Effects

FGT Foster-Greer-Thorbecke

$\mathrm{HH} \quad$ Head of Household

HIECS Household Income, Expenditure and Consumption Surveys

MDGs Millennium Development Goals

MLE Maximum Likelihood Estimation

SDGs Sustainable Development Goals

VIF Variance Inflation Factor 


\section{Introduction}

A world free of poverty is the dream of all international organizations and governments as well as civil society organizations across the globe. As a result, the first goal of the Millennium Development Goals (MDGs) for the year 2015 was to eliminate extreme poverty and hunger through halving the proportion of people whose daily income is less than $\$ 1.25$, followed by the Sustainable Development Goals (SDGs) for the year 2030, where its first goal is to eradicate extreme poverty for all people everywhere. However, it is not practical target due to the fact that poverty is a multifaceted phenomenon that includes different elements which may be economic, political or social.

Regarding the economic status in Egypt, the Egyptian economy is a developing one with many challenges and obstacles. It has been suffering from increasing poverty for a period of over 20 years. One of the causes of the 25 January Revolution in 2011 was poverty and low standard of living. The Egyptian economy is heavily dependent on the agriculture sector as well as the tourism sector. However, in recent years, the mentioned sectors faced several challenges and were not performing well. Political upheaval and fears of the lack of security have destroyed the country's vital tourism industry, leading to an increase of unemployment. In addition, the agriculture sector suffers from increasing urbanization and people's inclination to engage in more urban jobs. However, the agriculture sector remains a cornerstone of Egypt's economy, both in terms of overall value-added output and employment.

In 2014, the Egyptian government started implementing a bold and transformational reforms program that aimed to improve economic performance and enhance overall economic indicators. However, the extreme measures carried out by the government will affect the society's welfare negatively at first as it included reduction of government expenditures, subsidies degradation, and liberation of the Egyptian pound among others.

While poverty in Egypt has been no anomaly for years, poverty began to recede from 1995 to 2000. The percentage of the population living in poverty decreased from $19 \%$ to under $17 \%$. However, progress began to reverse itself. In 2005 and 2010, about $20 \%$ and $22 \%$ of the population respectively were living under the national poverty line. The previously mentioned reasons triggered a need for testing the effect on poverty incidence and poverty determinants in Egypt after the Revolution and after adopting a new strict economic program.

The objective of this research paper is to determine and model the different factors and determinants affecting poverty in Egypt using the three most recent Egyptian Households Income, Expenditure and Consumption Surveys (HIECS) conducted by the Central Agency for Public Mobilization and Statistics (CAPMAS) for the years 2011, 2013 and 2015. In order to analyze different aspects of poverty, the study constructed poverty profile for the years 2011, 2013 and 2015 and utilized two different econometric techniques to model the most important variables that influence consumption and poverty status; namely, Fixed Effects (FE) regression and Logistic regression.

The paper is structured as follows: The reviewed literature is presented in Section 2; Section 3 displays the poverty profile of Egypt for 2015, 2013 and 2011, and demonstrates the characteristic of poor individuals and households; Section 4 depicts the employed variables and models. Thereafter, the results of the two models are presented and discussed in Section 55. Section 6Error! 
Reference source not found. highlights and discusses the simulation process and its main findings and finally, Section 07 concludes the paper and presents possible poverty reduction policies.

\section{Literature Review}

Poverty has been examined and analyzed by several scholars over time. Poverty studies can be classified according to various dimensions, such as the utilized modelling techniques, the possible determinants in addition to the results. The results always include characteristics of the household itself as well as characteristics of the Head of Household $(\mathrm{HH})$.

Empirical studies employed different modelling techniques to model poverty determinants including FE regression, logistic regression as well as Quantile regression. However, the most widespread used techniques are FE regression and logistic regression (All, 2005).

FE regression is paramount when dealing with poverty modelling. It is necessary to not reduce a continuous variable, such as expenditures or income, and replace it with a qualitative variable, such as poor or not poor binary variable, since this would discard advantageous information (Deaton, 1997). Hence, FE regression has been employed in several studies to examine poverty determinants and to find the main household characteristics and factors affecting poverty (Mukherjee and Benson, 2003; Case et al., 2004; Datt and Jolliffe, 2005). Datt and Jolliffe (1999) estimated FE models for urban and rural regions in Egypt, followed by poverty changes from simulated policy changes. Moreover, El Laithy (2011) and El Laithy et al. (2003) examined the determinants affecting household consumption in Egypt using the same technique.

Additionally, logistic regression represented in logit and probit is key to examining the factors affecting the probability that household will be poor. El Laithy (2001) employed logistic regression to estimate the probability of being poor in Egypt. Iwasaki and El-Laithy (2013) focused on assessing poverty status in some areas in Cairo using binomial logit regression. Other scholars employed logistic regression to model the different demographic and socio-economic determinants of poverty in several countries, such as Rusnak (2012) in Poland, Sikander et al. (2008) in Pakistan, Achia et al. (2010) in Kenya, Mok et al. (2007) in Malaysia and Rahman (2013) in Bangladesh.

Different methods are used in order to decide whether the household is poor or non-poor to construct the binary dependent variable under logistic regression. Some studies endorsed nonmonetary approaches, such as assets indices of each household indicating whether the household is poor or not (Cortinovis et al., 1993; Sahn and Stifel, 2000; Booysen et al., 2008; Achia et al., 2010; Habyarimana et al., 2015). Other studies used monetary indicators to determine the poverty status of a household such as households' disposable income or consumption expenditures (Glew, 1991; Kabubo-Mariara, 2002; Mukherjee and Benson, 2003; Datt and Jolliffe, 2005; Akerele and Adewuyi, 2011).

The determinants of poverty differ from one country to another and from one sample to another (All, 2005). Past researches revealed that determinants of poverty are divided majorly in two groups: one concerning the head of the household's characteristics, and the other consisting of the household's characteristics. Accordingly, it was deduced that the most exhaustively studied poverty determinants include: gender, age, marital status, educational level and employment status of $\mathrm{HH}$, in addition to household size, number of earners per household, household residency place, dependency ratio and income (Ibid, 2005). 
Out of all poverty variables, education of $\mathrm{HH}$ is one of the most important determinants. The higher the level of education, the higher the welfare of a household and the lower the chance of being poor (Kabubo-Mariara, 2002; Mutherjee and Benson, 2003; Geda et al., 2005; Datt and Jolliffe, 2005; Litchfield and McGregor, 2008; Sikander et al., 2008; Akerele and Adewuyi, 2011; Edoumiekumo et al., 2014; Lekobane and Seleka, 2017). Additionally, average years of schooling in Egypt has a significant positive effect on per capita consumption (El Laithy, 2011; El Laithy et al., 2003). Achia et al. (2010) pointed out that the incidence of poverty has a negative relation with the level of education of $\mathrm{HH}$ in rural and urban areas.

Sikander et al. (2008) showed that age and gender of the $\mathrm{HH}$ affect the likelihood of being poor in Punjab. Achia et al. (2010) concluded that eventuality of falling in poverty rises as the age of HH increases. However, Rahman (2013) deduced that poverty is high for households headed by young heads or female heads. Likewise, El Laithy (2001) revealed that being a female hikes the probability of being poor by more than $2 \%$ in urban areas and $4 \%$ in rural ones. Similarly, El Laithy (2011), El Laithy et al. (2003), and Datt and Jolliffe (1999) found that female-headed households tend to have lower consumption levels in both urban and rural areas, which also lowers households living standards. Finally, in Mok et al. (2007), both HH genders were found to have almost equal probability of being poor.

Not only were the HH's education, age and gender important factors affecting poverty but the sector of employment was also found to be another important determinant (El Laithy et al., 2003). As an illustration, Rahman (2013) indicated that manufacturing worker heads are poorer than agricultural, transport, service and construction worker heads in Bangladesh. Moreover, El Laithy (2011) specified that in urban areas, households that have heads working in manufacturing, trade or services have higher per capita consumption level than those whose heads work in agriculture, or are unemployed in Egypt.

Regarding household attributes, it was realized that household size significantly showed a negative impact on poverty status of household. The larger the household size, the higher the tendency of being among the poor, due to more devoted resources by the household to meet subsistence level of living (Lanjouw and Ravallion, 1995; Baulch and McCulloh, 1998; SerumagaZake and Naude, 2002; Geda et al., 2005; Gounder, 2013; Lekobane and Seleka, 2017; Sikander et al., 2008). Similarly, Rahman (2013), Rusnak (2012), Mok et al. (2007) and Datt and Jolliffe (1999) disclosed that among the characteristics boosting the risk of being poor are the size of the household as well as the number of children under 14 and elderly persons. Likewise, Achia et al. (2010) argued that poverty is found to be highest for households with seven or more members.

In addition, high dependency ratio showed a negative effect on household welfare. To put it differently, the increase in the dependency ratio in a household, increases the probability of being poor (Geda et al., 2005; Litchfield and McGregor, 2008; Shete, 2010; Akerele and Adewuyi, 2011; Edoumiekumo et al., 2013; Dartanto and Nurkholis, 2013; Lekobane and Seleka, 2017). For instance, El Liathy (2001) detected that an extra unit in dependency ratio leads to almost $7 \%$ increase in the likelihood of being poor. Similarly, Sikander et al. (2008) divulged that a rise in the dependency ratio by one unit contributes to $4 \%$ increase in the possibility of being poor.

Furthermore, in Egypt, the results revealed that the place of residency of the household constitutes an important factor affecting the eventuality of being poor. In other words, the level of welfare and hence poverty differs across regions and governorates. El Liathy (2011) specified that upper rural areas suffer the most from the incidence of poverty followed by upper urban ones while 
the lowest suffering is the metropolitan region. Similarly, El Laithy (2001) claimed that in all regions of Egypt, rural areas suffer more from poverty than urban areas. The study concluded that poverty reduction programs should be targeted to governorates such as Assuit, Suhag and Benisuef as well as poor regions in Cairo and Alexandria. On the other hand, El Laithy et al. (2003) presented that higher levels of inequality are observed in urban areas than rural ones.

\section{Poverty Profile}

A poverty profile sets out the main realties of poverty, which is a multifaceted phenomenon. It presents how poverty varies across different categories and reveals the major characteristics of poor people. Therefore, it answers questions such as: "how does poverty vary across different areas?", "how can demographic characteristics affect poverty?", "what are the main sources of income for the poor?" and "how is poverty linked to educational attainment?", among others. As a matter of fact, those who fall in poverty share extra attributes more than just having low income; consequently, poverty profile construction is an important prerequisite for poverty alleviation policies and strategies. Poverty is always related to large families, unemployment, working in lowpaid jobs, high-dependence on HH, malnutrition, bad health status and low education levels. Accordingly, poverty analysis should concentrate on characteristics of the poor, not merely on percentage of poor households. In this study, the poverty profile will be examined in terms of national and regional poverty measures, demographic characteristics, employment status, educational attainment as well as inequality measures.

\subsection{Data}

The analysis of poverty determinants of households depends primarily on the most recent HIECS for the years 2011, 2013 and 2015, conducted by CAPMAS. The HIECS is generally considered the main source of information on household income and expenditure in Egypt. The HIECS data is harmonized, cleansed and provided by Economic Research Forum (ERF). The survey had been conducted every five years since 1955 up until 2009, after which it has since been conducted every two years. Furthermore, national lines for the three employed surveys as well as the relative rural, urban, and regional poverty lines-that take into account the different characteristics and price levels of each region-are calculated and provided by CAPMAS. The surveys cover all the 27 Egyptian governorates. The utilized samples consist of 7,719 households for the 2011 survey, 7,528 households for the 2013 survey and 11,988 households for 2015 the survey ${ }^{1}$.

\subsection{Poverty Measures}

The most widely utilized measures of poverty are the headcount ratio $\left(P_{0}\right)$, the poverty gap index $\left(P_{1}\right)$ and the poverty severity index $\left(P_{2}\right)$, which are derived from the class of Foster-Greer-

\footnotetext{
${ }^{1}$ The utilized samples represent $50 \%$ of total sample collected by CAPMAS, which is the maximum attainable data for researchers according to CAPMAS policy.
} 
Thorbecke (FGT) measurements (Foster et al.,1984). It is a class of decomposable poverty measures. For each $\alpha \geq 0$, let $P_{\alpha}$ be defined as follows;

$P_{\alpha}(y ; z)=\frac{1}{n} \sum_{i=1}^{q}\left(\frac{z-y_{i}}{z}\right)^{\alpha}$

where $y=\left(y_{1}, y_{2}, \ldots ., y_{n}\right)$ is a vector of household incomes or consumption, and $z>0$ is the predetermined poverty line. Additionally, $z-y_{i}$ is the income shortfall of the ith household, $q$ is the number of poor households (having income or consumption less than $z$ ), and $n=n(y)$ is the total number of households. Consequently, $P_{0}$ is the headcount ratio and it is obtained when $\alpha=0$. It measures the proportion of population who are counted as poor, in other words, it measures the prevalence and incidence of poverty. Further, $P_{1}$ is the poverty gap index, which is acquired when $\alpha=1$ and measures the depth of poverty. In other words, it demonstrates the extent to which individuals on average fall below the poverty line, and expresses it as a percentage of the poverty line. Furthermore, $P_{2}$ is the poverty severity index that is attained when $\alpha=2$. This measure reflects the severity of poverty because it implicitly puts more weight for observations that fall well below the poverty line.

\subsubsection{National Poverty Measures}

Since 2005 up to 2015, poverty in Egypt experienced a continuous increase. In 2005 and 2009 percentage of poor persons increased to reach $19.6 \%$ and $21.6 \%$ respectively according to the CAPMAS statistics. The number and percentage of poor individuals in the population are calculated based on poor households. Hence the poverty rate $P_{0}$ was calculated on the individuals' level for the three years 2011, 2013 and 2015 on the national, rural and urban levels and presented in Table 1.

Table 1: Percenatge of Poor Individuals (2011, 2013, 2015)

\begin{tabular}{|c|c|c|c|}
\hline \multirow{2}{*}{} & \multicolumn{3}{|c|}{ Headcount Rate $\boldsymbol{P}_{\mathbf{0}}(\boldsymbol{\%})$} \\
\cline { 2 - 4 } & $\mathbf{2 0 1 1}$ & $\mathbf{2 0 1 3}$ & $\mathbf{2 0 1 5}$ \\
\hline National & 25.7 & 27.5 & 29.8 \\
\hline Rural & 32.0 & 31.9 & 37.3 \\
\hline Urban & 15.8 & 19.7 & 18.9 \\
\hline
\end{tabular}

Source: Authors' calculations based on HICES provided by $\operatorname{ERF}(2011,2013,2015)$

It can be seen from Table 1 that the percentage of poor individuals in Egypt kept on increasing over time on the national level from $25.7 \%$ in 2011, up to $27.5 \%$ in 2013 then to $29.8 \%$ in 2015 . However, on the rural and urban levels it exhibited an inconsistent trend.

As far as household poverty is concerned, different poverty measures for the examined years 2011, 2013 and 2015 on national, rural and urban levels are depicted in Table 2. During recent years, the proportion of poor households and incidence, as well as severity of poverty in Egypt, increased continuously on the national level. Rural areas also faced an increasing level of poverty, while on the urban level, poverty sustained a changing trend. In 2015, 22.1\% of the households, representing about $29.8 \%$ of Egyptian population, lived in poverty. Speaking of rural residents, $28.3 \%$ of the households living there fall in poverty in 2015 compared to the $24.8 \%$ in 2013 . However, the headcount rate of poverty in urban areas exhibits a slight decrease in 2015 relative to 
its counterpart in 2013. Together, with the fact that all poverty measures are higher in the rural level than in the urban level, the poverty gap between rural and urban areas is increasing in Egypt over time.

Table 2: Poverty Measurements by Household (2011, 2013, 2015)

\begin{tabular}{|c|c|c|c|c|c|c|c|c|c|}
\hline & \multicolumn{4}{|c|}{ Headcount Rate $\boldsymbol{P}_{\mathbf{0}}(\boldsymbol{\%})$} & \multicolumn{3}{c|}{ Poverty Gap $\boldsymbol{P}_{\mathbf{1}}(\boldsymbol{\%})$} & \multicolumn{2}{|c|}{ Severity of Poverty $\boldsymbol{P}_{\mathbf{2}}(\boldsymbol{\%})$} \\
\cline { 2 - 10 } & $\mathbf{2 0 1 1}$ & $\mathbf{2 0 1 3}$ & $\mathbf{2 0 1 5}$ & $\mathbf{2 0 1 1}$ & $\mathbf{2 0 1 3}$ & $\mathbf{2 0 1 5}$ & $\mathbf{2 0 1 1}$ & $\mathbf{2 0 1 3}$ & $\mathbf{2 0 1 5}$ \\
\hline National & 18.8 & 20.8 & 22.1 & 3.7 & 4.0 & 4.4 & 1.1 & 1.2 & 1.3 \\
\hline Rural & 24.1 & 24.8 & 28.3 & 4.7 & 4.9 & 5.7 & 1.4 & 1.5 & 1.7 \\
\hline Urban & 11.3 & 14.4 & 13.7 & 2.2 & 2.4 & 2.4 & 0.6 & 0.6 & 0.6 \\
\hline
\end{tabular}

Source: Authors' calculations based on HICES provided by ERF $(2011,2013,2015)$

\subsubsection{Regional Poverty Measures}

According to the CAPMAS, the 27 Egyptian governorates are classified into seven regions: urban, lower urban, lower rural, upper urban, upper rural, border urban and border rural governorates, as illustrated in Appendix A, Table A-1. In order to assess the difference in poverty status in each region, poverty measures were calculated for each region separately.

Table 3 illustrates the poverty measurements in the seven regions within Egypt. As shown below, poverty measures are decreasing in urban governorates over years, while they fluctuate in border rural governorates with an increase from 2011 to 2013, and then decrease in 2015. Notably, upper rural governorates are the governorates suffering the most from poverty incidence as they have the highest values for all poverty measures in the three studied years. In addition, urban border governorates are getting worse as their poverty measures are consistently increasing over time. On the other hand, upper urban and lower urban governorates show low levels in poverty measures across the three years relative to other regions.

Table 3: Overall Poverty Measurements for the Seven Regions (2011, 2013, 2015)

\begin{tabular}{|c|c|c|c|c|c|c|c|c|c|}
\hline \multirow{2}{*}{ Region } & \multicolumn{3}{|c|}{ Headcount Rate $\boldsymbol{P}_{\mathbf{0}}(\boldsymbol{\%})$} & \multicolumn{3}{c|}{ Poverty Gap $\boldsymbol{P}_{\mathbf{1}}(\boldsymbol{\%})$} & \multicolumn{3}{c|}{$\begin{array}{c}\text { Severity of Poverty } \boldsymbol{P}_{\mathbf{2}} \\
(\boldsymbol{\%})\end{array}$} \\
\cline { 2 - 12 } & $\mathbf{2 0 1 1}$ & $\mathbf{2 0 1 3}$ & $\mathbf{2 0 1 5}$ & $\mathbf{2 0 1 1}$ & $\mathbf{2 0 1 3}$ & $\mathbf{2 0 1 5}$ & $\mathbf{2 0 1 1}$ & $\mathbf{2 0 1 3}$ & $\mathbf{2 0 1 5}$ \\
\hline Urban & 12.7 & 13.4 & 10.6 & 2.5 & 2.3 & 1.6 & 0.7 & 0.6 & 0.4 \\
\hline Lower Urban & 7.8 & 7.9 & 7.8 & 1.2 & 1.0 & 1.1 & 0.3 & 0.2 & 0.2 \\
\hline Lower Rural & 12.1 & 12.5 & 14.8 & 1.8 & 1.6 & 2.1 & 0.4 & 0.3 & 0.4 \\
\hline Upper Urban & 22.1 & 22.2 & 22.7 & 4.7 & 4.0 & 4.4 & 1.5 & 1.1 & 1.2 \\
\hline Upper Rural & 41.2 & 40.4 & 43.3 & 9.1 & 9.0 & 9.7 & 2.9 & 3.0 & 3.1 \\
\hline Border Urban & 3.7 & 11.9 & 15.4 & 0.5 & 1.8 & 4.1 & 0.0 & 0.4 & 1.5 \\
\hline Border Rural & 26.3 & 35.0 & 24.2 & 5.0 & 7.5 & 3.9 & 1.2 & 1.9 & 1.0 \\
\hline
\end{tabular}

Source: Authors' calculations based on HICES provided by ERF $(2011,2013,2015)$

The headcount ratios of the seven regions in 2011, 2013 and 2015 are depicted in

Figure 1. It can be noted that rural areas have a higher percentage of poor households than urban ones in all regions. Additionally, it shows that both rural and urban areas within Upper Egypt region have the highest proportion of poor households compared to other regions. 
Figure 1: Headcount Ratio of the Seven Regions (2011, 2013, 2015)

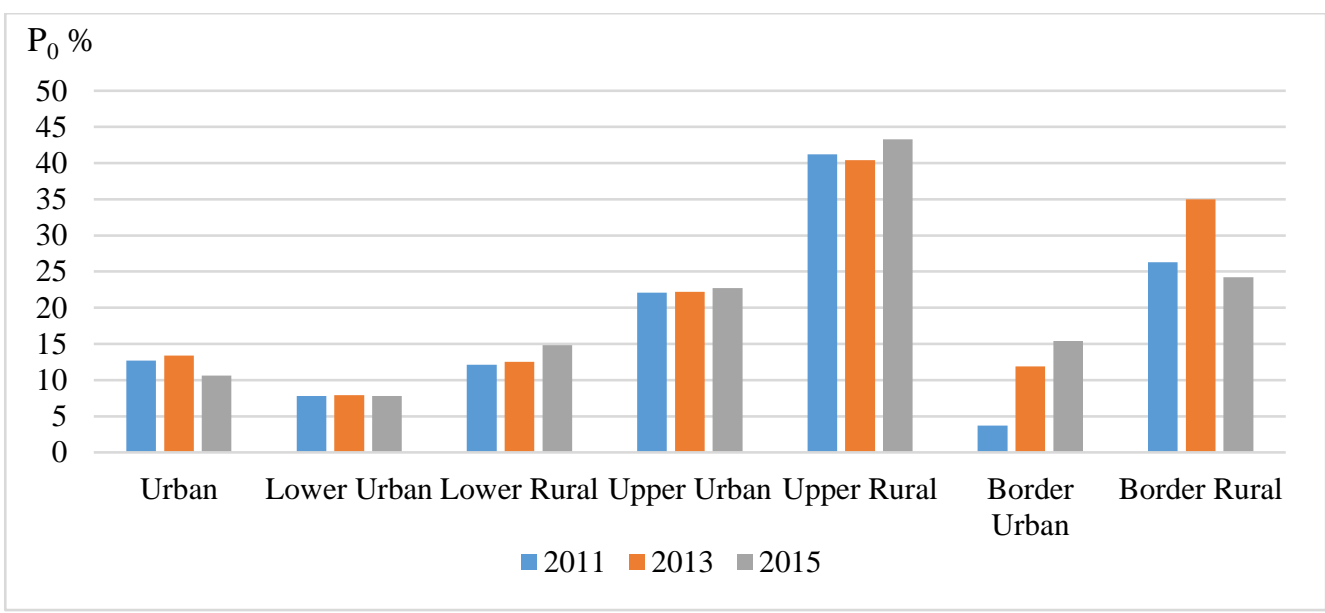

Source: Authors' calculations based on HICES provided by ERF $(2011,2013,2015)$

Figure 2 shows the headcount ratio of urban areas within governorates. As shown, the ones suffering the most are located in Assuit, Aswan, Beni Suef, Luxor, Qena and Suhag over the three surveys. It is noted that the aforementioned governorates are all located in Upper Egypt. In addition, urban areas suffering the least within governorates are in Alexandria, Dakahlia, Damietta, Kafr Elshekh, Sharkia, and Suez over the three surveys. It is also noted that those the governorates are located in the Lower Egypt region and considered urban governorates.

Figure 2: Headcount Ratio of Urban Areas in Governorates (2011, 2013, 2015)

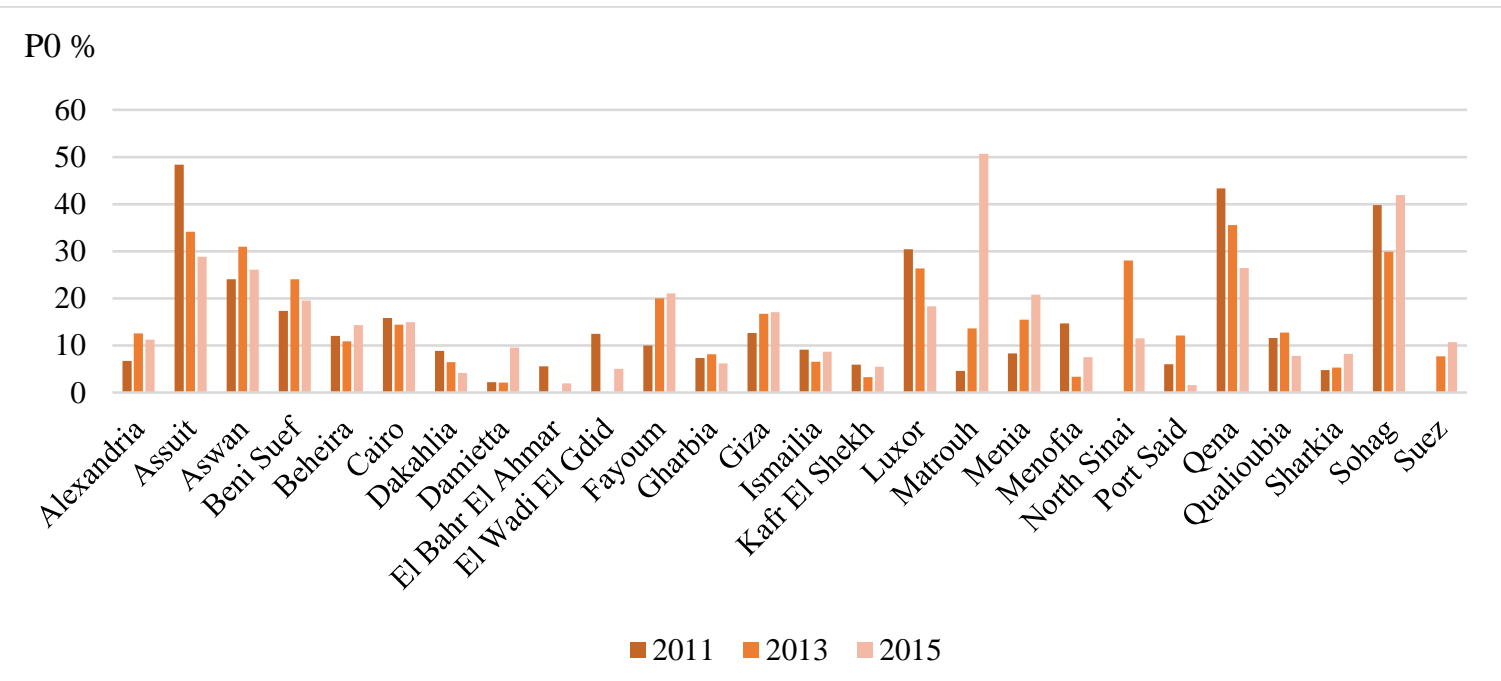

Source: Authors' calculations based on HICES provided by ERF (2011, 2013, 2015)

Governorates that endure the highest poverty incidence are in Upper Egypt, while the ones experiencing poverty the least are located in the Lower Egypt region as shown in Figure 3. Therefore, both figures indicate that the Upper Egypt region experiences large poverty measures whether in urban areas or in rural areas, whilst Lower Egypt and urban governorates are the ones with the highest level of prosperity. 
Figure 3: Headcount Ratio of Rural Areas in Governorates (2011, 2013, 2015)

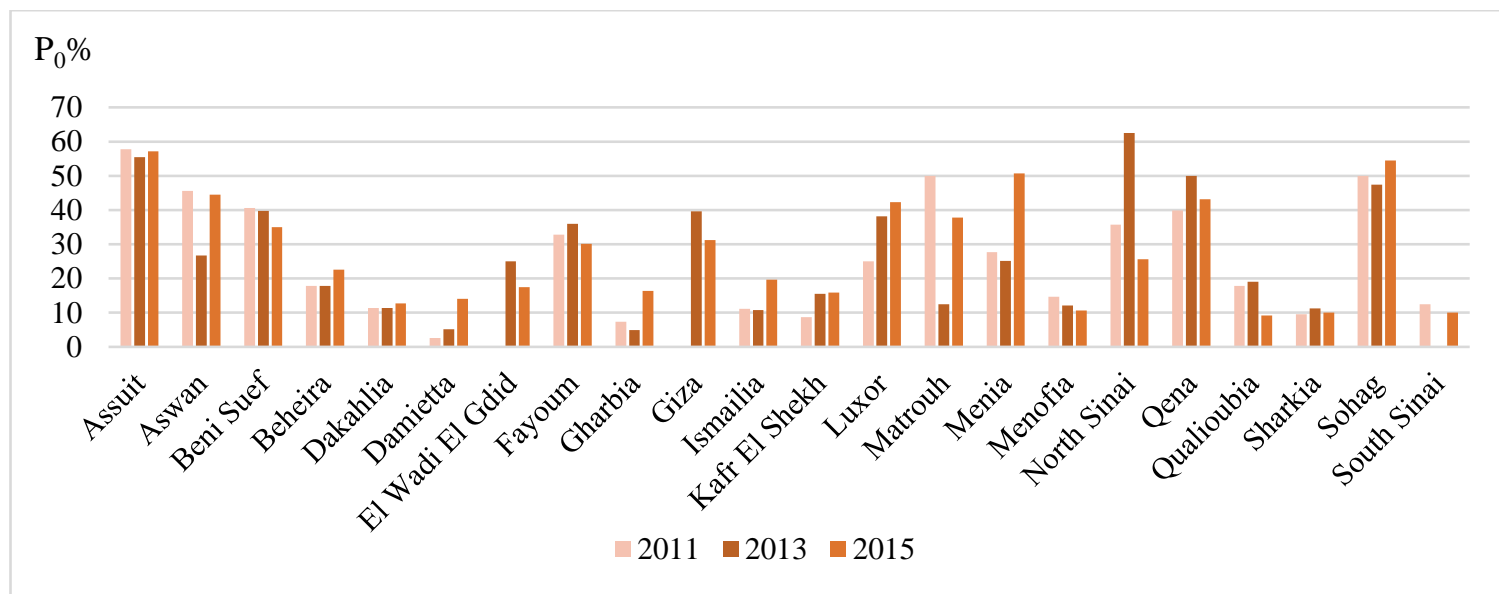

Source: Authors' calculations based on HICES provided by ERF $(2011,2013,2015)$

\subsection{Demographic Characteristics}

\subsubsection{Household Size}

Household size is one of the main determinants of poverty. Table A-2 in Appendix A as well as Figure 4 depict the effect of family size on the poverty status of households on three levels; namely, national, urban and rural levels. Over the three studied years, as the family size increases, poverty measures increased as well. Year 2015 registered the highest values in poverty measures, compared to the other two years with large families.

Figure 4: Headcount Ratio of Households Based on Family Size in 2015

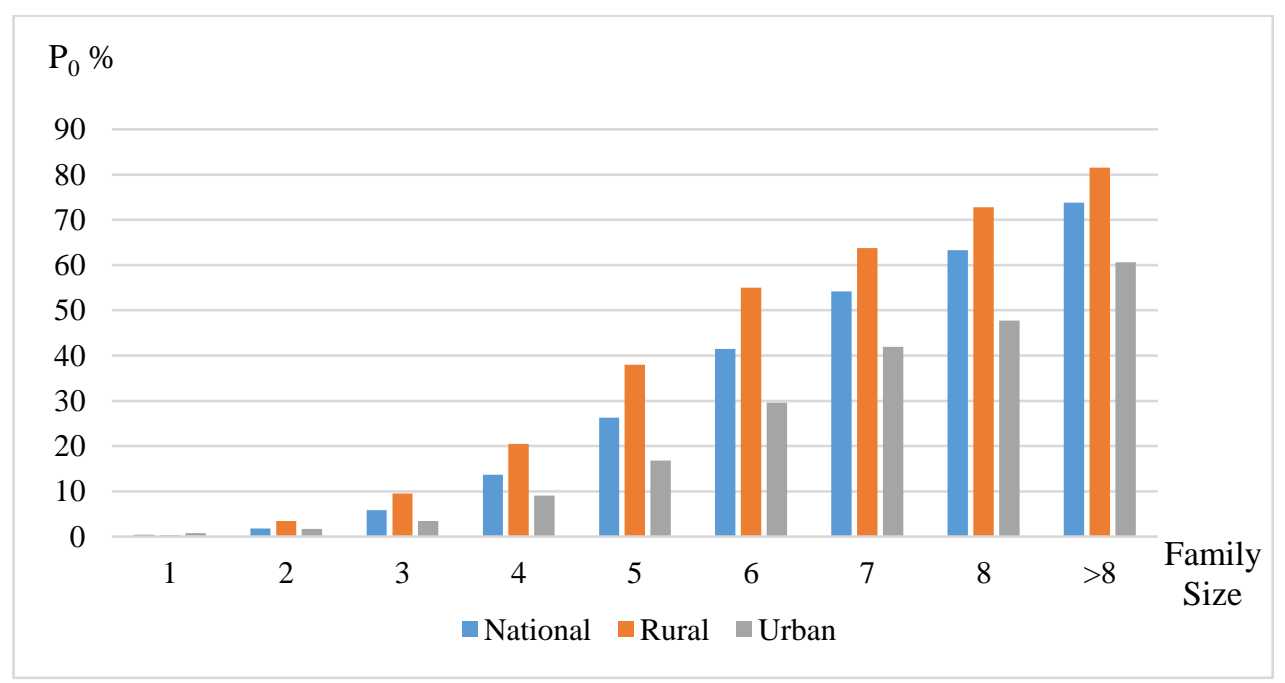

Source: Authors' calculations based on HICES provided by ERF (2015)

In addition, households in rural areas with large family size suffer more than their counterparts in urban areas with the same family size. For instance in year 2015, households with five individuals have a headcount ratio with a $21.1 \%$ higher in rural areas compared to urban areas. 


\subsubsection{Age of Head of Household}

Table A-3 in Appendix A shows how age of $\mathrm{HH}$ affects poverty over time on the national, rural and urban levels. It is observed that, over the three years and on the three levels, percentage of poor households hikes as $\mathrm{HH}$ age increases up to the age of 50 and then decreases. Furthermore, households headed by individuals in the two age groups (30-40 and 40-50) are found to have the highest poverty incidence among other households in the three years. In 2015, almost $31.7 \%$ and $29.1 \%$ from households headed by individuals in the previously mentioned age groups were found to be poor. This may be due to the high burden which those heads bear because of their children education expenditures and other consumption loads. It is worth mentioning that almost $21 \%$ and $25 \%$ of the households in 2015 are headed by persons in the previously mentioned age groups. In addition, percentage of poor households whose heads are aged between 20 and 50 years are higher on the rural level than on the urban level. Moreover, at age of 60 and above, heads of households are less probable to sustain spending loads as they are more likely to have adults who can be selfdependent.

\subsubsection{Gender of Head of Household}

Poverty indices by gender of the $\mathrm{HH}$ for national, rural and urban sectors are presented in Appendix A, Table A-4 and Figure 5. All measures imply a higher level of poverty among maleheaded households than female-headed households, especially in the rural sector in the three years. It can be noted that on the national and rural levels, poverty rates and severity of poverty are increasing over time for both $\mathrm{HH}$ genders. Meanwhile in urban areas, poverty rate for male-headed households endorsed an increase from $11.9 \%$ in 2011 to $16.9 \%$ in 2013 followed by a decrease to $14.7 \%$ in 2015 . Likewise, percentage of poor, female-headed households increased from $8.5 \%$ in 2011 to $10.5 \%$ in 2013 then declined to $8.9 \%$ in 2015 . In 2015, percentage of poor male-headed households was $8.4 \%, 10.8 \%$ and $5.8 \%$ higher than their female-headed counterparts on the national, rural and urban levels respectively.

Figure 5: Headcount Ratio of Households Based on Gender of Head of Household in 2015

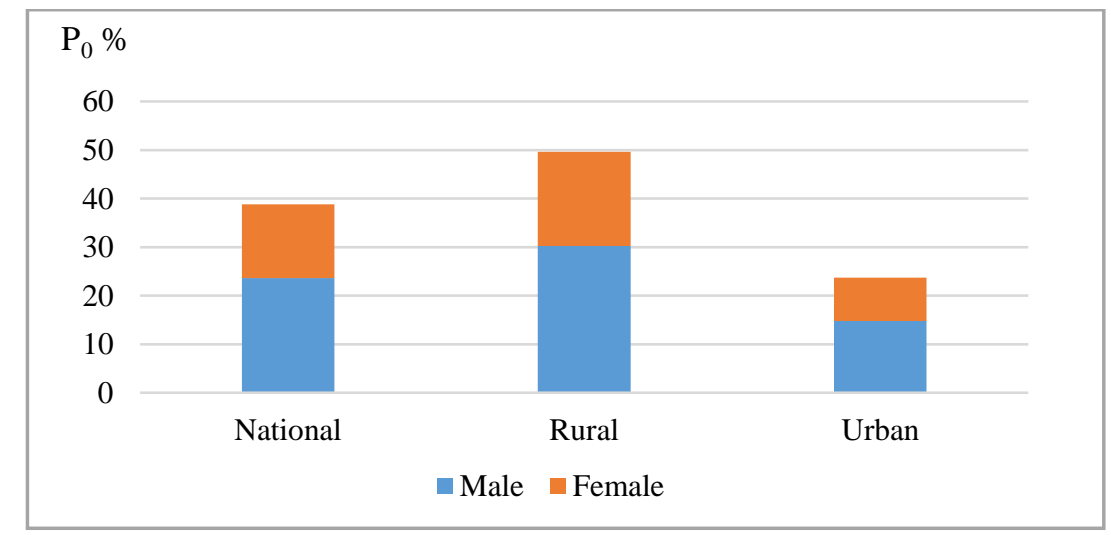

Source: Authors' calculations based on HICES provided by ERF (2015) 


\subsubsection{Marital Status of Head of Household}

Table A-5 depicts how marital status of $\mathrm{HH}$ affects poverty. It is evident that households headed by individuals who have not been married have the least poverty rate and incidence among other households. Notably, married households are characterized by having the highest poverty incidence on all levels of analysis. However, households living in rural areas whose heads are married are facing higher poverty prevalence than their urban counterparts. As an illustration, poverty rate for households headed by married persons is higher by $12.2 \%$ on average in rural areas than urban areas. Additionally, it can be concluded that incidence of poverty is increasing over time in all households under various heads of households' marital status. Furthermore, households headed by divorced or widowed heads are encountered moderate poverty risk across the three years compared to those headed by married people.

\subsection{Employment Status}

\subsubsection{Status of Employment of Head of Household}

Employment of $\mathrm{HH}$ can be of major impact on the poverty condition of a household. Its effect is depicted in Appendix A, Table A-6 and Figure 6. Households headed by employers are suffering the least from poverty according to poverty measures. On the other hand, households whose head are contributing (unpaid) family workers have the highest poverty incidence among other households on the three studied levels in 2015.

Figure 6: Headcount Ratio of Households Based on Head's Employment Status in 2015

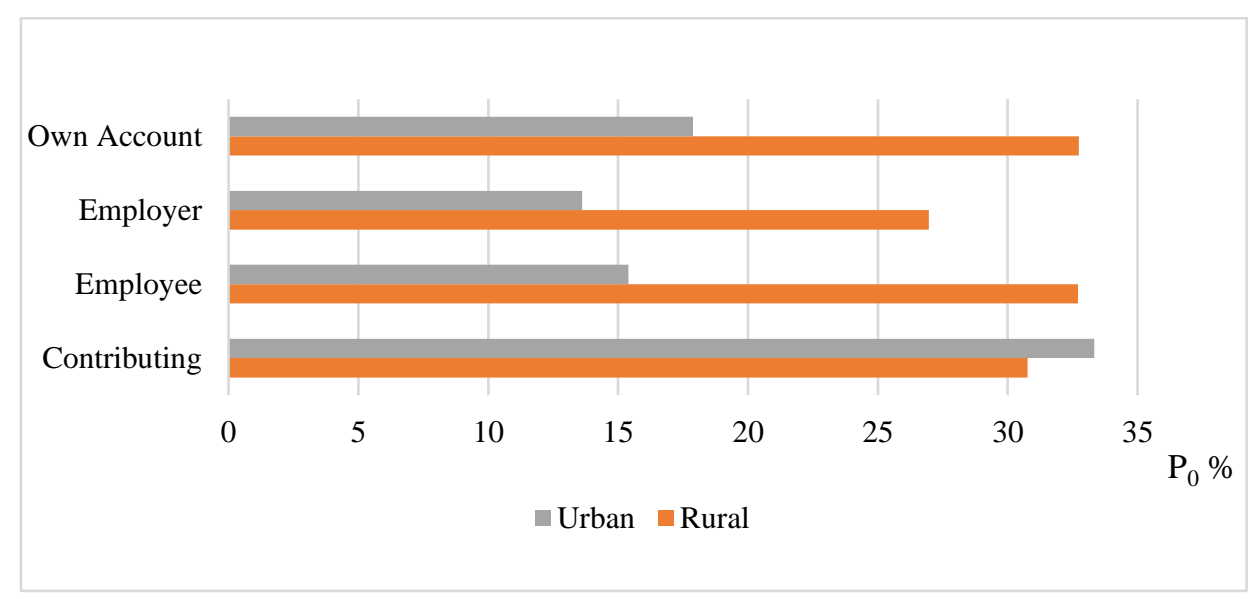

Source: Authors' calculations based on HICES provided by ERF (2015)

All status of employment studied shows an increasing trend in poverty measures across the three surveys. Moreover, under the same job category and the same year, rural families registered higher rates of poverty than urban families.

\subsubsection{Status of Employment of Spouse}

The employment status of the HH's first spouse is one of the main factors that affects poverty incidence. Table A-7 of Appendix A presents how poverty measure differs according to this factor. 
Over the three years, the work of the HH's spouse will help increase household's income and hence reduce poverty. On the national level, the percentage of poor households in which the first spouse is working decreased over time from $22.1 \%$ in 2011 to $21.2 \%$ in 2013 and $20.9 \%$ in 2015. On the other hand, the trend is reversed for households with a non-working spouse, where the percentage increased. The effect of employment of the first spouse contributes to lessening all poverty measures in urban areas, more than in rural areas in all the studied surveys. It is noted that poverty measures in rural areas kept increasing regardless of the employment status of the first spouse.

\subsubsection{Sector of Employment of Head of Household}

Table A-8 in Appendix A examines the effect of the sector of employment of the $\mathrm{HH}$ on poverty measures. As illustrated, at the national, urban and rural levels almost all poverty measures exhibit low levels for households headed by individuals who work in the public sector than other sectors, followed by government sector. Additionally, it is noted that a HH who works in any sector other than public and governmental sectors under the three examined levels causes poverty measures to increase across the three years. It is also noted that the rate of increase over the three surveys is much higher in rural areas than urban areas in any of the examined sectors.

\subsubsection{Industry of Employment of Head of Household}

indicates how poverty measures differ according to the industry of the $\mathrm{HH}$. For instance, on the rural and urban levels, households whose heads work in agriculture and construction suffer more from poverty than in other industries. Moreover, percentage of poor households whose heads are construction and agriculture workers was higher in rural areas than in urban areas. In 2015, percentage of poor households that were headed by individuals working in the agriculture industry in rural areas was $17.7 \%$ higher than their urban counterparts. On the other hand, households with heads working in services and public administration were better off.

Figure 7: Headcount Ratio of Households Based on Head's Employment Industry in 2015

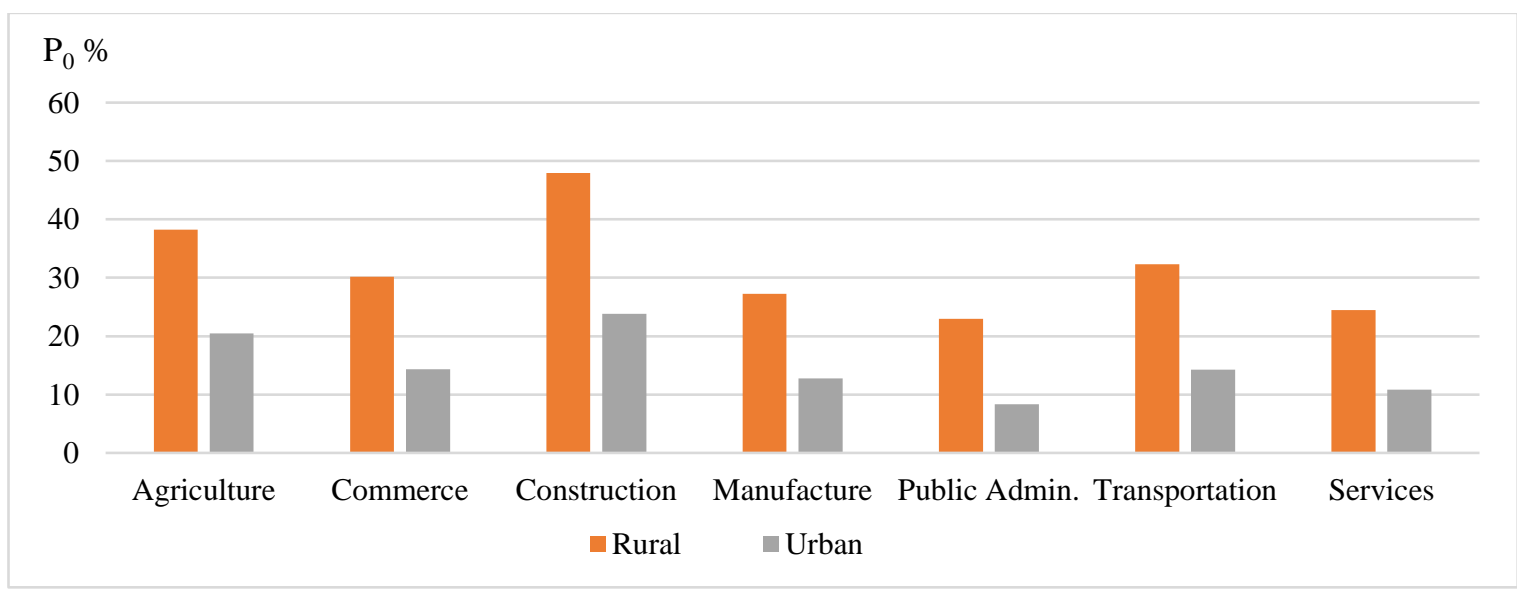

Source: Authors' calculations based on HICES provided by ERF (2015)

As the table demonstrates, the incidence of poverty for all studied categories is higher in rural regions than in urban regions even in industries that have the lowest poverty measures. This may 
be due to the fact that rural residents are engaged primarily in agriculture and construction, and to the low wages experienced in rural areas. In urban areas and across time, the severity of poverty was least among households with heads working in public administration namely, $0.28 \%, 0.35 \%$ and $0.28 \%$ in 2011,2013 and 2015 respectively.

\subsubsection{Number of Earners per Household}

Number of earners in a household is one of the important poverty determinants. It is expected that the more the earners in a household, the lower the possibility of being poor. However, as illustrated in Appendix A, Table A-9, poverty measures throughout the three surveys on the national, rural and urban levels have an overall positive relation between number of earners and the value of poverty measures, which is contrary to what is expected. For example in year 2015, the increase in number of earners from four to five is accompanied by an increase in poverty headcount ratio from $32.1 \%$ to $42.9 \%$ under the national level. A justification for that observation could be that: as the poverty incidence starts to inflate, household's members start to seek jobs and become earners to share the burden with the head.

\subsection{Educational Attainment}

\subsubsection{Literacy of Head of Household}

As depicted in Appendix A, Table A-10, the ability of the head to read and write contributes to reducing all three poverty measures. Year 2015 shows that households with illiterate heads suffered more than those with a literate head. Moreover, year 2015 shows that the percentage of poor households headed by literate individuals was $11.7 \%$ lower compared to those headed by illiterate heads on the national level.

Furthermore, poverty incidence in urban areas is more sensitive to literacy status of the $\mathrm{HH}$ than that in rural areas. For instance, in year 2015, the poverty headcount ratio for households headed by educated persons was lower than that for households headed by uneducated individuals by $11.2 \%$ in urban areas, and by $7.1 \%$ in rural areas. In addition, all measures of poverty illustrate that the poverty condition is getting worse over time, whether the head is able to read and write or not.

\subsubsection{Educational Level of Head of Household}

Table A-11 and Figure 8 present patterns of the educational level of the heads of households on the three levels of analysis. According to the data, almost $44 \%$ of heads of households are illiterate. It is obvious that poverty is negatively related to $\mathrm{HH}$ educational attainment and that the incidence of poverty increases with illiteracy on all levels especially in rural areas. In 2015, 28.6\% of households headed by illiterate persons fell in poverty on the national level, while the case was worse on the rural level where $31.7 \%$ of households whose heads are illiterate faced poverty compared to only $22.5 \%$ in urban areas. University and post-graduation education hinders the risk of falling in poverty mostly in urban areas, where in 2015 only $3.9 \%$ of households headed by university degree holders are poor. More importantly, there was no poor households headed by post-graduation degree holders on the urban level over years. 
Figure 8: Headcount Ratio of Households Based on Head's Educational Level in 2015

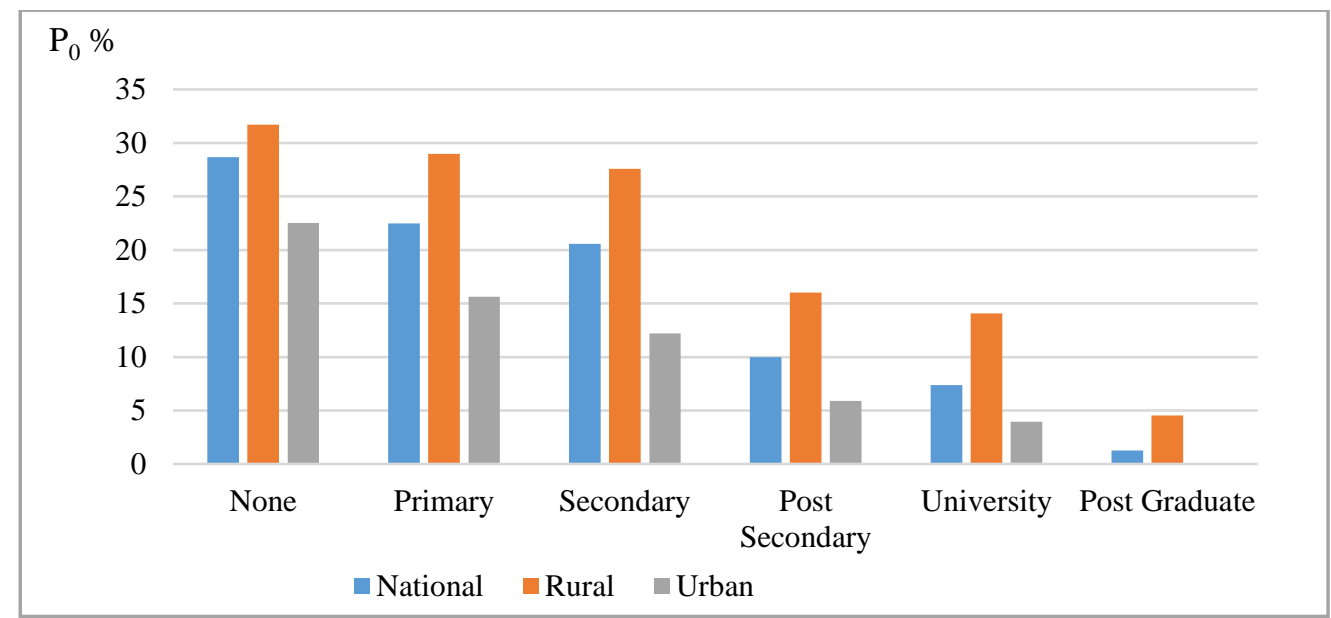

Source: Authors' calculations based on HICES provided by ERF (2015)

It can be noted also that the percentage of poor households headed by individuals with primary and secondary school education did not differ significantly. However, the percentage was smaller for households headed by secondary school graduates. To conclude, education improvement is of great importance in reducing poverty incidence in Egypt and protecting households from facing poverty, on all levels. Educated HHs have higher chances of being employed than illiterate ones.

\subsection{Income Inequality}

Income inequality is one of the main obstacles of poverty elimination. GINI coefficient is the most widely used measure for income inequality (All, 2005). It is based on the Lorenz curve, which plots shares of population against shares of income received (Deininger and Squire, 1996).

Gini $=1-\frac{1}{n} \sum_{i=1}^{n}\left(y_{i}-y_{i-1}\right)$

where $y_{i}$ is the income of person $i$ and $n$ is the sample size $(1,2,3 \ldots \mathrm{n})$.

According to the World Bank, Egypt is a moderate country in income inequality compared to the rest of the world, based on GINI index with an average of $31.3 \%$ for the seven recent HIECS surveys since 1990, up to 2015 (World Bank Data, 2018).

Decomposition of GINI coefficient from the national level to urban and rural is of great importance for policy targeting. The decomposition of GINI coefficient is made for the three surveys under examination; namely, for the years 2011, 2013 and 2015. As can be seen in Figure 9, the values of GINI coefficient for urban and rural areas in Egypt for the 2011, 2013 and 2015 surveys.

Figure 9: Inequality Measures for Rural and Urban areas (2011, 2013, 2015) 


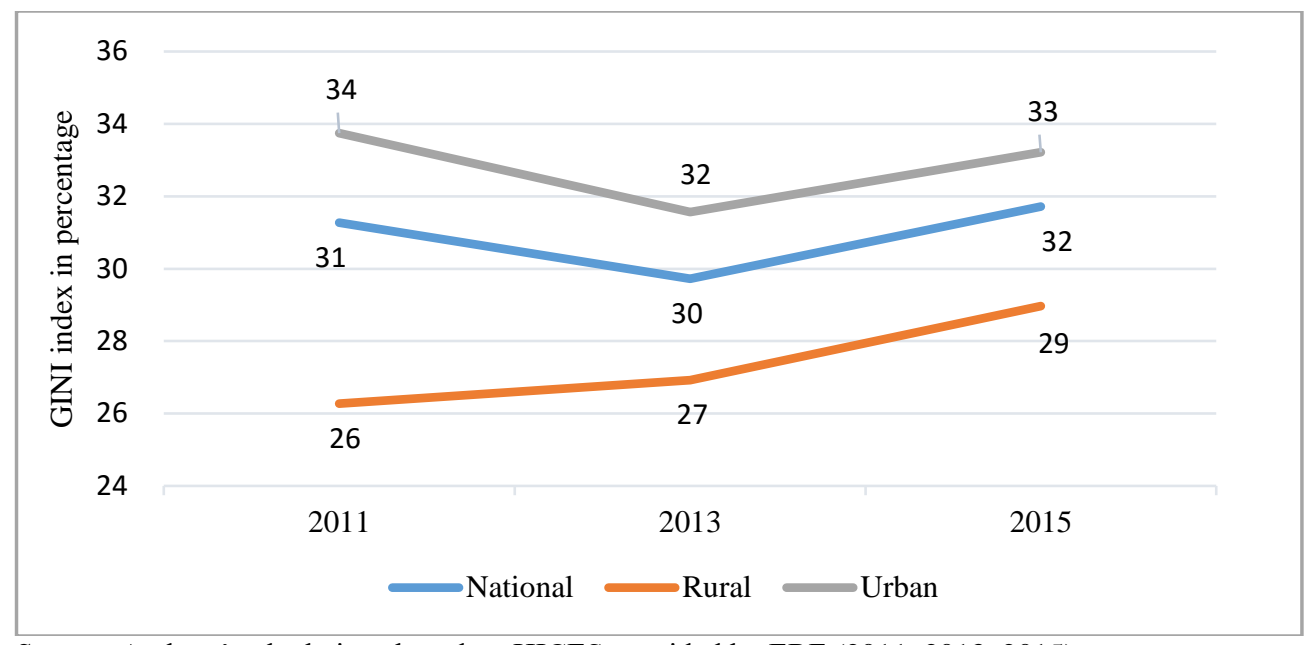

Source: Authors' calculations based on HICES provided by ERF $(2011,2013,2015)$

It is noted that urban income inequality is higher than that in rural areas; however, rural inequality keeps increasing over time with no fluctuations, which means it is more of a problem. Rural inequality increased from 2011 to 2015 by 3\%, while urban inequality increased by only $1 \%$ over the same interval. As explained by the poverty profile, rural areas suffer more from poverty incidence than urban areas. However, inequality seems to have more values for urban areas. Further analysis is needed to examine the factors contributing to and affecting inequality and how this could impact poverty incidence as a separate research study.

\section{Methodology}

Poverty measures for different households' characteristics are helpful to painting a poverty profile, however, it does not provide the marginal contribution of each factor's influence on poverty. Moreover, it does not indicate any causality. Accordingly, regression analysis are advantageous to tackle these issues. It shows the marginal effect of each determinant and its incidence on poverty while holding all other influences constant.

\subsection{Model Specification}

The research objective is to estimate the effect of important explanatory variables on poverty in Egypt. Upon reviewing the literature - and according to poverty profile results - household demographic characteristics, employment characteristics, number of earners per household, dependency ratio for each household, health, and education were identified as important determinants affecting poverty in Egypt. As mentioned earlier, data of the HIECS surveys of more than approximately 7,719, 7,528 and 11,988 household in Egypt for 2011, 2013 and 2015 respectively is used to achieve the aim of this paper. Therefore, cross section data was employed in the three analyzed years successively. Factors affecting poverty and their proxies are illustrated in Appendix B, Table B-1. 


\subsection{Regression Models}

In order to achieve the goal of this research, two econometric techniques were utilized; namely, FE regression and logistic regression. Both regression models estimate the effect of the same explanatory variables on the dependent variable of each model.

\subsubsection{Fixed Effects Regression Model}

FE regression is the typical regression model employed to examine the poverty determinants as it helps control variables that cannot be included in the model (Allison, 2009).

Egypt has 27 governorates; each one has its own administrative entity, prices, agro-climatic conditions, educational efficiency, and employment opportunities, among others. Governoratespecific effects appear to be reasonably adequate for controlling for potentially omitted variables. FE was introduced only at the governorate level to control the omitted variable biasness.

The FE model specification is as follows:

$\ln C_{i}=\beta_{1} X_{1 i}+\beta_{2} X_{2 i}+\beta_{3} X_{3 i}+\cdots+\beta_{j} X_{j i}+\alpha_{i}+u$

where, $\ln C_{i}$ is the natural $\log$ of consumption expenditures for $i$ household, $X_{i}$ is the observed regressor for household $i$, and they go up to $n$ number of households $(i=1,2,3, \ldots, n), j$ is the number of explanatory variables and it arises up to $m$ number of variables $(j=1,2,3, \ldots, m)$, and $\alpha_{i}=\beta_{0}+\beta_{i} Z_{i}$ is the intercept and it varies for each governorate due to the effect of $Z_{i}$, which is unobserved variable, but constant within the same governorate (governorate-specific intercept).

The estimated functional form is a semi log form, specifically log-linear form. Therefore, estimated coefficients refer to the percentage change in consumption expenditures as caused by the absolute change in the explanatory variables, multiplied by 100 .

\subsubsection{Logistic Regression Model}

Logistic regression has been used to study the relationship between a dichotomous dependent variable (being poor or not) and a set of independent variables explaining the probability of a household to fall into poverty. The main objective of the analysis is to identify the key factors that may affect poverty status of households and to determine how these factors influence the risk of poverty of a household. With the logistic model one can interpret the dependent variable as the log odds ratio that a particular event occurs given specific values of the explanatory variables (Gujarati and Porter, 2009).

A logistic model is a univariate binary model. For dependent variable $Y_{i}$, there are only two values one if the event occurs and zero otherwise, and set of independent variables $X_{i}$, that

$P_{i}\left(Y_{i}=1\right)=F\left(\beta X_{i}\right)$

where $\beta$ is a parameter, which needs to be estimated and $F$ is logistic Cumulative Distribution Function (CDF).

The general form of Logistic model is: 
$P_{i}=F\left(\alpha+\beta X_{i}\right)=\frac{1}{\left[1+e^{-\left(\alpha+\beta X_{i}\right)}\right]}$

If $P_{i}$ is the probability of being poor, then $\left(1-P_{i}\right)$ is probability of not being poor, which is represented as follows.

$1-P_{i}=\frac{1}{\left[1+e^{\left(\alpha+\beta X_{i}\right)}\right]}$

$\frac{P_{i}}{1-P_{i}}=\frac{1+\left[e^{\left(\alpha+\beta X_{i}\right)}\right]}{1+\left[e^{-\left(\alpha+\beta X_{i}\right)}\right]}=e^{\left(\alpha+\beta X_{i}\right)}$

where $\frac{P_{i}}{1-P_{i}}$ is the odds ratio in favor of being poor. The natural $\log$ of the odds ratio is the Logit which is called $\mathrm{L}$ as follows;

$L_{i}=\ln \left(\frac{P_{i}}{1-P_{i}}\right)=\alpha+\beta X_{i}+\varepsilon_{i}$

Furthermore, the estimation of the logistic regression parameters uses the maximum likelihood estimation (MLE) technique. A positive sign of the estimated coefficients would mean that the probability of being poor is higher than reference category and vice versa, keeping all other characteristics constant. Putting it another way: a number greater than one of log odds indicates a positive association between independent and dependent variables, while a number between zero and one indicates negative association between them.

\section{Regression Results}

In this section, the results of the two fitted regression models for the three years 2011, 2013 and 2015 are presented, examined and discussed.

\section{1. $\quad$ Fixed Effects Regression Results}

Table 4 illustrates the results of the FE model for the years 2011, 2013 and 2015 and depicts the effect of different variables on the consumption expenditures of households. The model accuracy of estimation is checked through testing for multicollinearity through the variance inflation factor (VIF) test, as well as checking for heteroscedasticity through a BreuschPagan/Cook-Weisberg test. Table C-1 and C-2 in 
Appendix C illustrate that both post estimation tests show that the model is clear from multicollinearity and heteroscedasticity.

Table 4: Fixed Effects Regression Results (2015, 2013, 2011)

\begin{tabular}{|c|c|c|c|c|c|c|}
\hline \multirow{2}{*}{ Variable } & \multicolumn{2}{|c|}{2015} & \multicolumn{2}{|c|}{2013} & \multicolumn{2}{|c|}{2011} \\
\hline & Coeff & t-stat & Coeff & t-stat & Coeff & t-stat \\
\hline \multicolumn{7}{|l|}{ Demographic Characteristics } \\
\hline $\begin{array}{l}\text { Residency: } \\
\text { Urban } \\
\text { Rural } \\
\end{array}$ & $-0.080 * * *$ & -10.32 & $-0.121 * * *$ & -7.52 & $-0.137 * * *$ & -10.42 \\
\hline Family size & $0.108 * * *$ & 47.55 & $0.149 * * *$ & 34.04 & $0.109 * * *$ & 31.60 \\
\hline Age of $\mathrm{HH}$ & $0.004 * * *$ & 12.13 & $0.002 * * *$ & 3.72 & $0.002 * * *$ & 5.12 \\
\hline $\begin{array}{l}\text { Gender of } \mathbf{H H :} \\
\text { Female } \\
\text { Male } \\
\end{array}$ & $\begin{array}{l}0.035^{* *} \\
-\end{array}$ & 2.26 & $\begin{array}{l}0.034 \\
- \\
\end{array}$ & 1.13 & $\begin{array}{l}0.109 * * * \\
-\end{array}$ & 4.23 \\
\hline $\begin{array}{l}\text { Marital status of HH: } \\
\text { Never married } \\
\text { Married } \\
\text { Divorced } \\
\text { Widowed } \\
\end{array}$ & $\begin{array}{l}-0.176 * * * \\
-0.166 * * * \\
-0.134 * * *\end{array}$ & $\begin{array}{l}-6.68 \\
-6.88 \\
-9.10 \\
\end{array}$ & $\begin{array}{l}-0.213 * * * \\
-0.127 * * \\
-0.166 * * *\end{array}$ & $\begin{array}{l}-4.34 \\
-2.39 \\
-5.30 \\
\end{array}$ & $\begin{array}{l}-0.141 * * * \\
-0.281 * * * \\
-0.190 * * *\end{array}$ & $\begin{array}{l}-3.84 \\
-5.56 \\
-7.34 \\
\end{array}$ \\
\hline \multicolumn{7}{|l|}{ Employment Status } \\
\hline $\begin{array}{l}\text { Employment of HH: } \\
\text { Unemployed } \\
\text { Employed } \\
\text { Pensioner }\end{array}$ & $\begin{array}{l}0.117 * * * \\
0.241 * * * \\
-\end{array}$ & $\begin{array}{l}7.93 \\
5.99\end{array}$ & $\begin{array}{l}0.054 * \\
0.011 \\
-\end{array}$ & $\begin{array}{l}1.66 \\
0.21\end{array}$ & $\begin{array}{l}-0.021 \\
-0.053 \\
-\end{array}$ & $\begin{array}{l}-0.80 \\
-1.33\end{array}$ \\
\hline $\begin{array}{l}\text { Employment of HH first spouse: } \\
\text { Unemployed } \\
\text { Employed } \\
\text { Pensioner }\end{array}$ & $\begin{array}{l}0.034 * \\
0.054 * * * \\
-\end{array}$ & $\begin{array}{l}1.77 \\
2.73\end{array}$ & $\begin{array}{l}-0.089 \\
-0.043 \\
-\end{array}$ & $\begin{array}{l}-1.62 \\
-0.77\end{array}$ & $\begin{array}{l}-0.168 * * * \\
-0.157 * * * \\
-\end{array}$ & $\begin{array}{l}-3.45 \\
-3.14\end{array}$ \\
\hline $\begin{array}{l}\text { Industry of employment of HH: } \\
\text { Agriculture } \\
\text { Commerce } \\
\text { Construction and electricity } \\
\text { Manufacturing } \\
\text { Public administration } \\
\text { Transportation } \\
\text { Services } \\
\text { Others }\end{array}$ & $\begin{array}{l}-0.047 * * * \\
-0.004 \\
0.004 \\
-0.014 \\
0.061 * * * \\
-0.022 * \\
- \\
0.161 * * *\end{array}$ & $\begin{array}{l}-3.75 \\
-0.31 \\
0.35 \\
-1.06 \\
4.55 \\
-1.64 \\
\\
4.05\end{array}$ & $\begin{array}{l}-0.023 \\
0.030 \\
0.061 * * \\
0.026 \\
0.033 \\
0.055^{*} \\
- \\
0.020\end{array}$ & $\begin{array}{l}-0.73 \\
0.99 \\
2.05 \\
0.89 \\
1.17 \\
1.80 \\
\\
0.36\end{array}$ & $\begin{array}{l}0.109 * * * \\
0.078 * * * \\
0.074 * * * \\
0.057 * * \\
0.001 \\
0.086 * * * \\
- \\
0.029\end{array}$ & $\begin{array}{l}4.41 \\
3.14 \\
3.15 \\
2.45 \\
0.06 \\
3.52 \\
\\
\\
0.72\end{array}$ \\
\hline $\begin{array}{l}\text { Sector of employment of HH: } \\
\text { Public sector } \\
\text { Private sector } \\
\text { Others }\end{array}$ & $\begin{array}{l}0.041 * * * \\
0.003 \\
-\end{array}$ & $\begin{array}{l}3.02 \\
0.38\end{array}$ & $\begin{array}{l}0.111 * * * \\
0.070 * * * \\
-\end{array}$ & $\begin{array}{l}3.94 \\
3.06\end{array}$ & $\begin{array}{l}0.097 * * * \\
0.063 * * * \\
-\end{array}$ & $\begin{array}{l}4.43 \\
3.55\end{array}$ \\
\hline Number of earners & $0.059 * * *$ & 12.82 & $0.100 * * *$ & 10.75 & $0.046 * * *$ & 6.50 \\
\hline Dependency ratio & $-0.055 * * *$ & -11.25 & $-0.100 * * *$ & -9.28 & $-0.032 * * *$ & -4.34 \\
\hline $\begin{array}{l}\text { Source of income: } \\
\text { Salaries and wages } \\
\text { Remittances } \\
\text { Household business } \\
\text { Others }\end{array}$ & $\begin{array}{l}-0.031 * * * \\
0.123 * * * \\
0.149 * *\end{array}$ & $\begin{array}{l}-2.88 \\
15.51 \\
2.10 \\
\end{array}$ & $\begin{array}{l}-0.104 * * * \\
0.110 * * * \\
-0.0875\end{array}$ & $\begin{array}{l}-4.31 \\
6.56 \\
-0.72 \\
\end{array}$ & $\begin{array}{l}- \\
0.108 * * * \\
-0.085 * * * \\
0.394 * * *\end{array}$ & $\begin{array}{l}-4.30 \\
8.18 \\
4.78 \\
\end{array}$ \\
\hline \multicolumn{7}{|l|}{ Health } \\
\hline Health expenditures (000 EGP) & $0.05 * * *$ & 35.80 & $0.19 * * *$ & 34.77 & $0.12 * * *$ & 22.80 \\
\hline
\end{tabular}




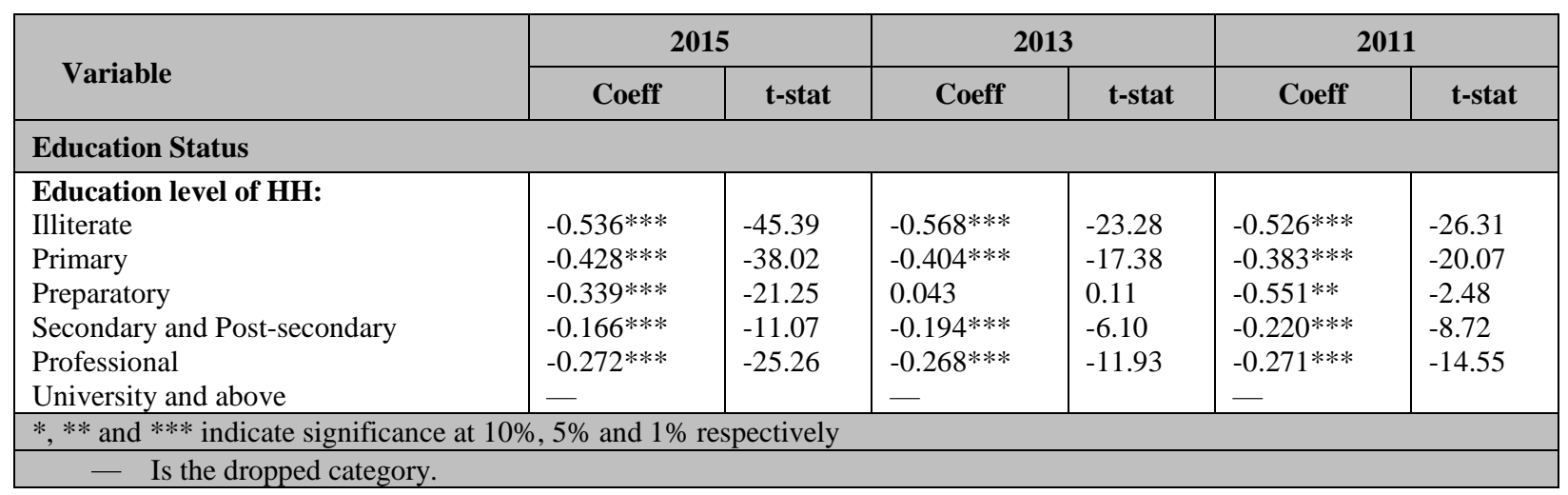

The results of the FE regression model are consistent with the literature. The higher the consumption expenditures of a household, the lower the chance of being poor. Out of all the studied variables, residency, family size, age of head, number of earners, marital status of head, medical expenditures, dependency ratio and educational level of head are the persistent determinants that affect poverty condition of a household across the three studied surveys.

Households reside in urban regions consistently have a higher opportunity of having lower levels of poverty, as consumption levels in urban areas are higher than those in rural areas. Consumption of a household in rural areas was lower than that in urban areas by $14 \%, 12 \%$ and $8 \%$ in the years 2011, 2013 and 2015 respectively.

Additionally, the results show that the higher the number of individuals in a household, the higher level of the household's consumption, which leads to a lower opportunity of being poor. Age of $\mathrm{HH}$ is one of the main factors affecting poverty incidence consistently. As illustrated from the results in the three studied years, the higher the age of $\mathrm{HH}$, the higher the consumption levels which is consistent with intuition as the older a person gets, the higher the level of income obtained and hence the higher the consumption level. In 2015, an increase in age of HH by one year causes an increase in consumption by $0.4 \%$ while all other variables remain constant.

Households headed by females tend to have higher levels of consumption than households headed by males. In 2015, households headed by females had a 3.5\% higher consumption expenditure per person than those headed by males. In addition, households headed by females in 2011 tended to have an $11 \%$ higher consumption per person than households with male heads with a $1 \%$ significance level.

Marital status of $\mathrm{HH}$ shows a clear, significant result: married heads are in a better position compared to being divorced, widowed or even single, as married heads suffer less from poverty, which is derived by having higher level of consumption expenditures. In 2015, married heads had higher consumption expenditures levels by $17.6 \%, 16.6 \%$ and $13.4 \%$ over single, divorced and widowed heads respectively.

In addition, employment status of a $\mathrm{HH}$ affects poverty positively and the results show that households with employed heads enjoy a higher level of individual consumption than unemployed and pensioners. A working spouse also helps increase consumption and reduce poverty. Households with pensioner heads and spouses had lower consumption expenditures by $35 \%$ and $37.3 \%$ over households with employed ones in 2015 respectively.

Furthermore, heads who work for the public sector have households with higher level of consumption than those households with heads who work for the private sector. In addition, the results present that there is no consistency in the effect direction of the HH's employment industry 
on households' poverty incidence over time. For instance, households with heads working in agriculture were better off than those with heads working in services in year 2011 by having $10.9 \%$ higher consumption spending. Yet, this turned to be the inverse in year 2015 as agriculture workersheaded households tended to have $4.7 \%$ lower consumption than service workers-headed households which is indicative that the agriculture industry experienced deterioration over those years while services sector has improved over time.

Dependency ratio represents the burden on a household's member of working age class and it is positively related with poverty incidence. The higher the number of individuals in a family relative to the individuals of working age in that family, the lower the household's consumption expenditure and the higher the chance of suffering from poverty. An increase in dependency ratio by $1 \%$ caused a decrease in consumption expenditure by $6.2 \%$ on average over the three years.

Regarding the source of income of $\mathrm{HH}$, the model shows that families who had heads with wages and salaries were in a better position compared to families with heads who depended on remittances by having $3.1 \%$ higher consumption, in 2015. However, heads with a private or household business, or even with a rent of owned dwellings, suffered less from poverty than heads with wages, salaries or remittances. In 2015, heads of households with a private business had $12.3 \%$ higher consumption expenditures and a lower chance of suffering poverty than those with wages or salaries.

Moreover, the results reveals that health expenditures per person contribute to increasing a household's consumption and thus lessen poverty incidence. When medical expenditures increased by 1,000 Egyptian pounds, consumption per person tended to increase by $5 \%, 19 \%$ and $12 \%$ in the years 2011, 2013 and 2015 respectively.

According to the literature, education is the most important factor that contributes to reducing poverty. In addition, poverty profile shows that as the level of education increases, poverty measures exhibit low levels. The results confirm both presumptions. In 2015, the results indicate that consumption of a household with a head who had a university degree or above was $54 \%, 43 \%$, $34 \%, 17 \%$, and $27 \%$ higher than that of a household with a head with no education at all, or with the following educational levels: primary, preparatory, secondary and professional levels respectively. Approximately, we can find the same outcome in the other two studied years.

\subsection{Logistic Regression Results}

One of the benefits of employing logistic regression is the ability to appraise the impact that a change in a particular variable would have on the probability of a household being poor, holding other factors constant. The results of the logistic models for the three modeled years 2015, 2013 and 2011 are presented in Table 5 including the estimated coefficients and the odds ratio. The odds ratio gives the change in the odds of being poor as opposed to not being poor, in response to a one unit change in the explanatory variables in case of continuous regressors whereas, in the case of dummy predictors, it refers to the difference between the reference category and other categories. Consequently, odds ratios less than one indicate that higher values of the independent variable are associated with decreasing poverty. Similarly, odds ratios greater than one reveal that an individual with a higher value of the independent variable is more likely to fall in poverty. The logistic coefficient could be interpreted as the change in log odds associated with one unit change in the explanatory variables. 
Table 5: Logistic Regression Results (2015, 2013, 2011)

\begin{tabular}{|c|c|c|c|c|c|c|c|c|c|}
\hline \multirow[b]{2}{*}{ Variable } & \multicolumn{3}{|c|}{2015} & \multicolumn{3}{|c|}{2013} & \multicolumn{3}{|c|}{2011} \\
\hline & $\begin{array}{l}\text { Odds } \\
\text { Ratio } \\
\end{array}$ & Coeff & z-stat & $\begin{array}{l}\text { Odds } \\
\text { Ratio } \\
\end{array}$ & Coeff & z-stat & $\begin{array}{l}\text { Odds } \\
\text { Ratio } \\
\end{array}$ & Coeff & z-stat \\
\hline \multicolumn{10}{|l|}{ Demographic Characteristics } \\
\hline $\begin{array}{l}\text { Residency: } \\
\text { Urban } \\
\text { Rural }\end{array}$ & $-133 * * *$ & $0.757 * * *$ & -11.8 & $\overline{1.881 * * *}$ & $0.631 * * *$ & 7.77 & $-124 * * *$ & $0.753 * * *$ & 8.90 \\
\hline Family size & $1.875^{* * *}$ & $0.628 * * *$ & 26.67 & $1.765^{* * *}$ & $0.568 * * *$ & 21.14 & $1.755^{* * *}$ & $0.562 * * *$ & 20.82 \\
\hline Age of $\mathrm{HH}$ & $0.973 * * *$ & $-0.026 * * *$ & -7.68 & $0.986^{* * *}$ & $-0.013 * * *$ & -3.56 & $0.981 * * *$ & $-0.018^{* * *}$ & -4.64 \\
\hline $\begin{array}{l}\text { Gender of } \mathbf{H H :} \\
\text { Female } \\
\text { Male }\end{array}$ & $\begin{array}{l}0.577 * * * \\
-\end{array}$ & $-0.548 * * *$ & -3.19 & $\begin{array}{l}0.540 * * * \\
-\end{array}$ & $-0.615 * * *$ & -2.93 & $\begin{array}{l}0.537 * * * \\
-\end{array}$ & $-0.620 * * *$ & -2.86 \\
\hline $\begin{array}{l}\text { Marital status of HH: } \\
\text { Never married } \\
\text { Married } \\
\text { Divorced } \\
\text { Widowed } \\
\end{array}$ & $\begin{array}{l}0.752 \\
- \\
2.035^{* * *} \\
1.265 \\
\end{array}$ & $\begin{array}{l}-0.284 \\
0.710^{* * * *} \\
0.235\end{array}$ & $\begin{array}{l}-0.72 \\
2.62 \\
1.49 \\
\end{array}$ & $\begin{array}{l}0.982 \\
- \\
2.141 * * \\
1.058 \\
\end{array}$ & $\begin{array}{l}-0.017 \\
0.761 * * \\
0.057 \\
\end{array}$ & $\begin{array}{l}-0.04 \\
2.24 \\
0.27\end{array}$ & $\begin{array}{l}1.203 \\
- \\
2.018^{*} \\
1.209 \\
\end{array}$ & $\begin{array}{l}0.184 \\
0.702 * \\
0.189 \\
\end{array}$ & $\begin{array}{l}0.49 \\
1.7 \\
0.9 \\
\end{array}$ \\
\hline \multicolumn{10}{|l|}{ Employment Status } \\
\hline $\begin{array}{l}\text { Employment of HH: } \\
\text { Unemployed } \\
\text { Employed } \\
\text { Pensioner } \\
\end{array}$ & $\begin{array}{l}0.648 * * \\
0.350 * * * \\
-\end{array}$ & $\begin{array}{l}-0.433 * * \\
-1.048 * * *\end{array}$ & $\begin{array}{l}-2.44 \\
-2.61\end{array}$ & $\begin{array}{l}0.984 \\
1.100 \\
-\quad \\
\end{array}$ & $\begin{array}{l}-0.019 \\
0.098\end{array}$ & $\begin{array}{l}-0.07 \\
0.27\end{array}$ & $\begin{array}{l}1.144 \\
0.963 \\
- \\
\end{array}$ & $\begin{array}{l}0.172 \\
0.037\end{array}$ & $\begin{array}{l}0.69 \\
0.12\end{array}$ \\
\hline $\begin{array}{l}\text { Employment of HH first } \\
\text { spouse: } \\
\text { Unemployed } \\
\text { Employed } \\
\text { Pensioner } \\
\end{array}$ & $\begin{array}{l}0.556^{* *} \\
0.373^{* * *} \\
-\end{array}$ & $\begin{array}{l}-0.585 * * \\
-0.985 * * *\end{array}$ & $\begin{array}{l}-2.32 \\
-3.8\end{array}$ & $\begin{array}{l}5.872 * * \\
4.229 * * \\
-\end{array}$ & $\begin{array}{l}1.770 * * \\
1.442 * *\end{array}$ & $\begin{array}{l}2.3 \\
1.86\end{array}$ & $\begin{array}{l}0.932 \\
0.822 \\
-\end{array}$ & $\begin{array}{l}0.125 \\
0.196\end{array}$ & $\begin{array}{l}1.02 \\
0.38\end{array}$ \\
\hline $\begin{array}{l}\text { Industry of employment of } \\
\text { HH: } \\
\text { Agriculture } \\
\text { Commerce } \\
\text { Construction and electricity } \\
\text { Manufacturing } \\
\text { Public administration } \\
\text { Transportation } \\
\text { Services } \\
\text { Others }\end{array}$ & $\begin{array}{l}1.475^{* *} \\
1.069 \\
1.229 * \\
0.723^{* *} \\
0.592^{*} * * \\
0.822 * * * \\
- \\
0.621\end{array}$ & $\begin{array}{l}0.388 * * \\
0.066 \\
0.206 * \\
-0.323 * * \\
-0.523 * * * \\
-0.194 * * * \\
-0.476\end{array}$ & $\begin{array}{l}3.32 \\
0.52 \\
1.72 \\
-2.48 \\
-3.84 \\
-1.53 \\
\\
-1.21\end{array}$ & $\begin{array}{l}0.633^{* *} \\
1.037 \\
0.691^{* *} \\
0.719^{*} \\
0.614^{* * *} \\
0.557^{* * *} \\
- \\
1.247\end{array}$ & $\begin{array}{l}-0.456^{* *} \\
0.036 \\
-0.369^{* *} \\
-0.328^{*} \\
-0.487^{* * *} \\
-0.584^{* * *} \\
0.220\end{array}$ & $\begin{array}{l}-2.55 \\
0.2 \\
-2.14 \\
-1.89 \\
-2.76 \\
-3.24 \\
\\
0.63\end{array}$ & $\begin{array}{l}0.685 * * \\
0.865 \\
0.678 * * \\
0.666 * * \\
0.897 * * * \\
0.589 * * * \\
- \\
0.898\end{array}$ & $\begin{array}{l}-0.377 * * \\
-0.144 \\
-0.387 * * \\
-0.405^{* *} \\
-0.108^{* * *} \\
-0.529 * * * \\
-0.107\end{array}$ & $\begin{array}{l}-2.16 \\
-0.77 \\
-2.26 \\
-2.36 \\
-0.61 \\
-2.92 \\
\\
-0.36\end{array}$ \\
\hline $\begin{array}{l}\text { Sector of employment of HH: } \\
\text { Public sector } \\
\text { Private sector } \\
\text { Others }\end{array}$ & $\begin{array}{l}0.528 * * * \\
0.590 * * * \\
-\end{array}$ & $\begin{array}{l}-0.637 * * * \\
-0.526 * * *\end{array}$ & $\begin{array}{l}-2.94 \\
-4.95\end{array}$ & $\begin{array}{l}0.489 * * * \\
0.566 * * * \\
-\end{array}$ & $\begin{array}{l}-0.714 * * * \\
-0.568 * * *\end{array}$ & $\begin{array}{l}-4.43 \\
-4.52\end{array}$ & $\begin{array}{l}0.458 * * * \\
0.645 * * * \\
-\end{array}$ & $\begin{array}{l}-0.780 * * * \\
-0.437 * * *\end{array}$ & $\begin{array}{l}-4.97 \\
-3.56\end{array}$ \\
\hline Number of earners & 1.000 & 0.000 & 0 & $0.785^{* * * *}$ & $-0.241 * * *$ & -4.71 & $0.858 * * *$ & $-0.152 * * *$ & -3.05 \\
\hline Dependency ratio & $1.686^{* * *}$ & $0.522 * * *$ & 11.35 & $1.875^{* * *}$ & $0.629 * * *$ & 10.45 & $1.736^{* * *}$ & $0.551 * * *$ & 9.29 \\
\hline $\begin{array}{l}\text { Source of income: } \\
\text { Salaries and wages } \\
\text { Remittances } \\
\text { Household business } \\
\text { Others }\end{array}$ & $\begin{array}{l}-\overline{0.985} \\
0.597 * * * \\
1.000\end{array}$ & $\begin{array}{l}-0.014 \\
-0.515^{*} \\
0\end{array}$ & $\begin{array}{l}-0.12 \\
-7.07\end{array}$ & $\begin{array}{l}\overline{2.286 * * *} \\
1.670^{* * *} \\
1.000\end{array}$ & $\begin{array}{l}0.826 * * * \\
0.513 * * * \\
0\end{array}$ & $\begin{array}{l}8.72 \\
3.09\end{array}$ & $\begin{array}{l}- \\
1.419 \\
1.150 \\
0.627\end{array}$ & $\begin{array}{l}0.350 \\
0.140 \\
-0.466 \\
\end{array}$ & $\begin{array}{l}0.3 \\
0.12 \\
\\
-0.4 \\
\end{array}$ \\
\hline \multicolumn{10}{|l|}{ Health } \\
\hline Health expenditures & $0.997 * * *$ & $-0.002 * * *$ & -23.6 & $0.996 * * *$ & $-0.003 * * *$ & -19.5 & $0.994 * * *$ & $-0.005^{* * *}$ & -20 \\
\hline Educational Status & & & & & & & & & \\
\hline
\end{tabular}




\begin{tabular}{|c|c|c|c|c|c|c|c|c|c|}
\hline \multirow[b]{2}{*}{ Variable } & \multicolumn{3}{|c|}{2015} & \multicolumn{3}{|c|}{2013} & \multicolumn{3}{|c|}{2011} \\
\hline & $\begin{array}{l}\text { Odds } \\
\text { Ratio } \\
\end{array}$ & Coeff & z-stat & $\begin{array}{l}\text { Odds } \\
\text { Ratio } \\
\end{array}$ & Coeff & z-stat & $\begin{array}{l}\text { Odds } \\
\text { Ratio } \\
\end{array}$ & Coeff & z-stat \\
\hline $\begin{array}{l}\text { Education level of } \mathbf{H H :} \\
\text { Illiterate } \\
\text { Primary } \\
\text { Preparatory } \\
\text { Secondary and Post-secondary } \\
\text { Professional } \\
\text { University and above }\end{array}$ & $\begin{array}{l}12.309 * * \\
5.568 * * * \\
4.098^{* * *} \\
1.694^{* * *} \\
3.037 * * * \\
-\end{array}$ & $\begin{array}{l}2.510 * * \\
1.717 * * * \\
1.410 * * * \\
0.527 * * * \\
1.110 * * *\end{array}$ & $\begin{array}{l}17.54 \\
12.46 \\
8.12 \\
2.83 \\
8.34\end{array}$ & $\begin{array}{l}2.546 * * * \\
1.256 * * * \\
1 \\
0.654 * * * \\
0.329 * * * \\
-\end{array}$ & $\begin{array}{l}0.934 * * * \\
0.228 * * * \\
0 \\
-0.424 * * * \\
-1.109 * * *\end{array}$ & $\begin{array}{l}8.85 \\
2.24 \\
\\
-2.24 \\
-6.48\end{array}$ & $\begin{array}{l}2.371 * * * \\
1.309 * * \\
4.636 \\
0.657 * * \\
0.356 * * * \\
-\end{array}$ & $\begin{array}{l}0.863 * * * \\
0.269 * * \\
1.533 \\
-0.418 * * \\
-1.031 * * *\end{array}$ & $\begin{array}{l}7.9 \\
2.52 \\
1.09 \\
-2.17 \\
-5.42\end{array}$ \\
\hline
\end{tabular}

The results of the logistic regression model are consistent with the outcome of the FE model, the poverty profile, as well as the literature. Among all explanatory variables, residency of household, family size, age and gender of $\mathrm{HH}$, industry and sector of employment of $\mathrm{HH}$, medical expenditures as well as $\mathrm{HH}$ educational attainment are the main affecting variables along the three examined years.

In the demographic characteristics category, almost all the explanatory variables have significant coefficients as poverty determinants for the three estimated models. Moreover, the results reveal that, keeping other variables the same, rural residents were more probable to be poor than urban areas' inhabitants. Particularly, the odds of falling in poverty were nearly twice as high among rural area residents than their urban counterparts in the three modeled years.

Additionally, as indicated by the estimated coefficients $(0.62),(0.56)$ and $(0.56)$ for family size in 2015, 2013 and 2011 respectively, households with larger size are more likely to be poor than those with smaller size. In other words, an extra family member increased the odds of being poor by $87 \%, 77 \%$ and $76 \%$ in 2015, 2013 and 2011 respectively $^{2}$. Furthermore, age of HH was negatively associated with the odds of being poor - that is, with each additional year of HH agethe probability that the household fall in poverty decreases by $2 \%$ on average over years. Speaking of the gender of $\mathrm{HH}$, there were almost $18 \%$ female-headed households on average. The results revealed that, households headed by females were better off with lower chances of being poor than households headed by males. As an illustration, male-headed households are $70 \%$ more likely to suffer from poverty. Concerning the marital status of the $\mathrm{HH}$, the effect was not highly different except between divorced and married heads. Specifically, eventuality of being poor for households headed by divorced persons was almost twice higher than that of households headed by married individuals.

Regarding employment status, most of the variables also had significant coefficients over the three years. In 2015, households with employed heads had less probability of falling into poverty than those headed by pensioners. Similarly, households in which the first spouse was employed, were less likely to suffer from poverty than households in which the first spouse was a pensioner, in 2015. For the industry of employment of $\mathrm{HH}$, the likelihood of being poor for households headed by individuals working in agriculture is $48 \%$ higher than for those headed by persons working in the services industry, in 2015. Inversely, in 2013 and 2011, agriculture workers were less probable to have poor households than services workers. The same trend held true for heads who work in construction and electricity industries. For the three studied years, 2015, 2013 and 2011, it was

\footnotetext{
${ }^{2}$ Percentage change is calculated as follows: (Odds Ratio- 1 )*100
} 
estimated that if the dependency ratio is increased by $1 \%$, the odds ratio would be increased by $52 \%, 62 \%$ and $55 \%$ respectively.

As far as expenditures on health are concerned, households with higher per capita medical expenditures are less likely to be poor. That is, a one pound increase in the medical expenses per person in a household decreases the probability of being poor by about $0.05 \%$ on average. Increasing medical expenditures would lead to better health conditions and hence better opportunities for work and other life activities.

As mentioned in the poverty profile, it is obvious that poverty is negatively related to the educational level of the $\mathrm{HH}$ and that the likelihood of falling into poverty increases with the propagation of illiteracy among individuals. Speaking of $\mathrm{HH}$ educational attainment, the estimated coefficient for illiterate heads (2.51) in 2015, suggests a higher chance of being poor for households with illiterate heads than those headed by university degree holders. This fitted model indicates that, holding other variables at a fixed value, the odds for households with primary educated heads are 55\% lower than the odds for their illiterate counterparts, implying that households whose heads have at least basic education are better off than those headed by illiterate ones. It can be noted that the higher the educational attainment of $\mathrm{HH}$, the lower the likelihood of the household to be poor.

\section{Simulation}

Having estimated the two poverty models, we move on to simulate poverty reduction policies and plans. The goal of the simulation is twofold. The first is to figure out the influence of changes in the levels of determinants of poverty on probability of being poor. The second is to show the possible consequences and effects of potential poverty lessening policies and plans.

Simulation results for 2015 are depicted in Appendix DD, Table D-1. The table illustrates how the probability of poverty differs according to different levels of variables such as: family size, gender and marital status of $\mathrm{HH}$; working status of both $\mathrm{HH}$ and spouse; working industry and educational attainment of the head; in addition to household's main source of income. The results revealed that in 2015 , an extra family member increased the probability of being poor at all levels of family size, however, an extra person had a higher influence in larger households. Additionally, family size had a greater effect in rural areas than urban ones. To illustrate, holding all variables the same for a household, a household that consisted of four members in rural areas had a $7 \%$ higher probability of falling in poverty than those in urban areas. To conclude, large households have a higher chance of being poor compared to small ones where increasing the household by one person increases the probability of poverty as illustrated in Figure 10. This necessitates the need for some policies to encourage lessening number of births, and to promote family planning programs.

Figure 10: The Predicted Effect of Family Size on Poverty in Egypt 


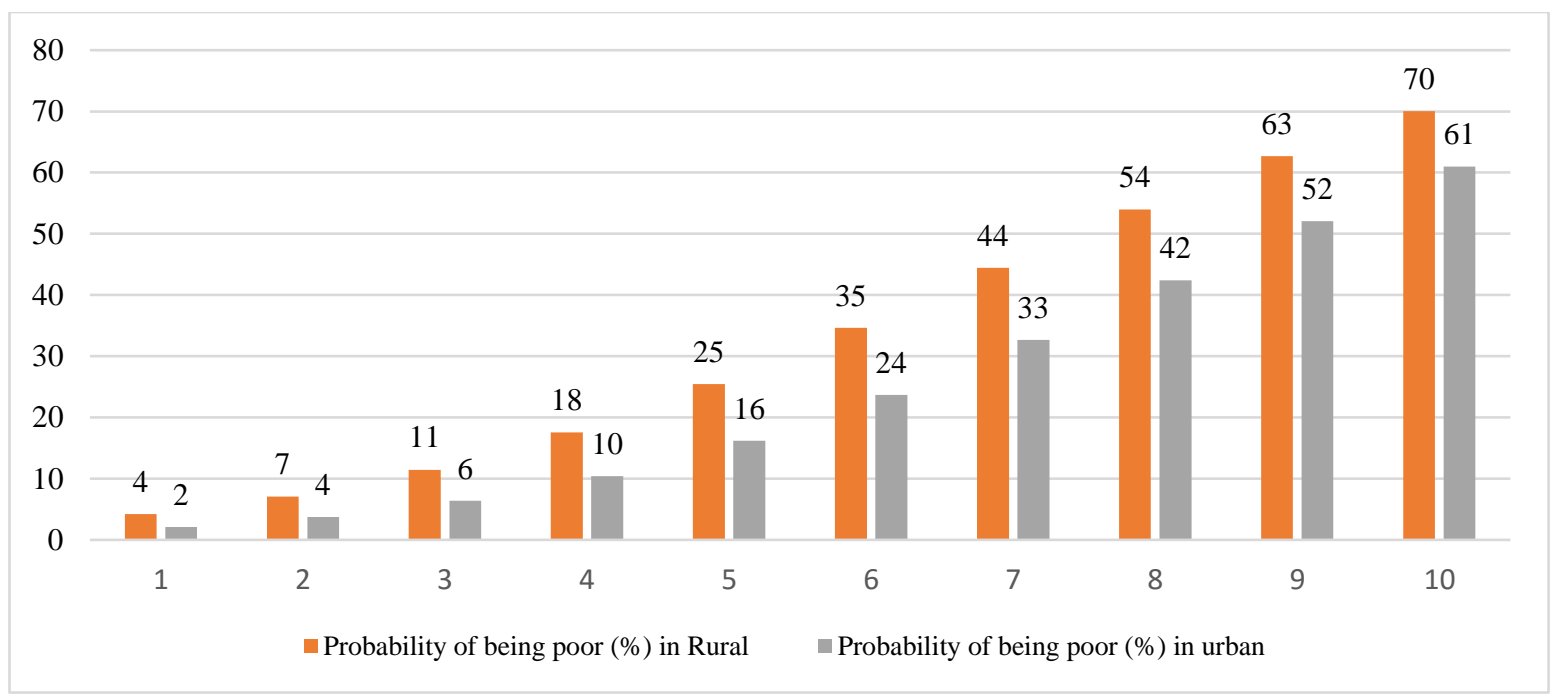

Source: Table D-1, Appendix D.

Furthermore, households headed by females have less eventuality of falling into poverty than households headed by males in both urban and rural areas. However, female-headed households have an almost 7\% higher chance of being poor in rural areas than urban ones. Similarly, in rural areas, male-headed households are $8 \%$ more likely to fall into poverty than in urban areas. As far as the marital status of $\mathrm{HH}$ is concerned, it is obvious that divorced heads are more anticipated to live in poor households than other households, followed by widowed heads for both genders. However, male-headed households are still associated with a higher probability of being poor under all marital status conditions. The previously mentioned reasons demonstrate a demand of assistance for rural areas as well as divorced heads.

Moreover, households with an employed head and first spouse have the least probability of being poor among other households; namely, $17.7 \%$. Those are followed by households in which the head is employed, with a probability of $21.5 \%$ of being poor. On the other hand, households whose head and first spouse are either pensioners or unemployed suffer the most from poverty with a $34.9 \%$ and $40.1 \%$ probability of being poor respectively. As such, serious policies are needed to target those households.

Concerning heads of households' working industry, in both rural and urban areas, households with heads working in the agriculture sector were the highest in facing the risk of being poor among other households, with about $31 \%$ and $22 \%$ probability of being poor in rural and urban areas respectively. By way of contrast, households headed by persons working in the public administration sector are the least likely to be poor in urban and rural areas. Moreover, changes in the employment sector of the head from "agriculture" to "manufacturing" would reduce poverty by $6 \%$ in urban areas and by $8 \%$ in rural areas. There was no big difference in the likelihood of falling into poverty for households headed by persons working in commerce and services sectors as illustrated in Figure 11. Therefore, the agriculture sector in Egypt needs huge attention in order to enhance the living standards of families and people depending on the agriculture sector as their main working industry.

Figure 11: The Predicted Effect of Working Industry on Poverty in Egypt 


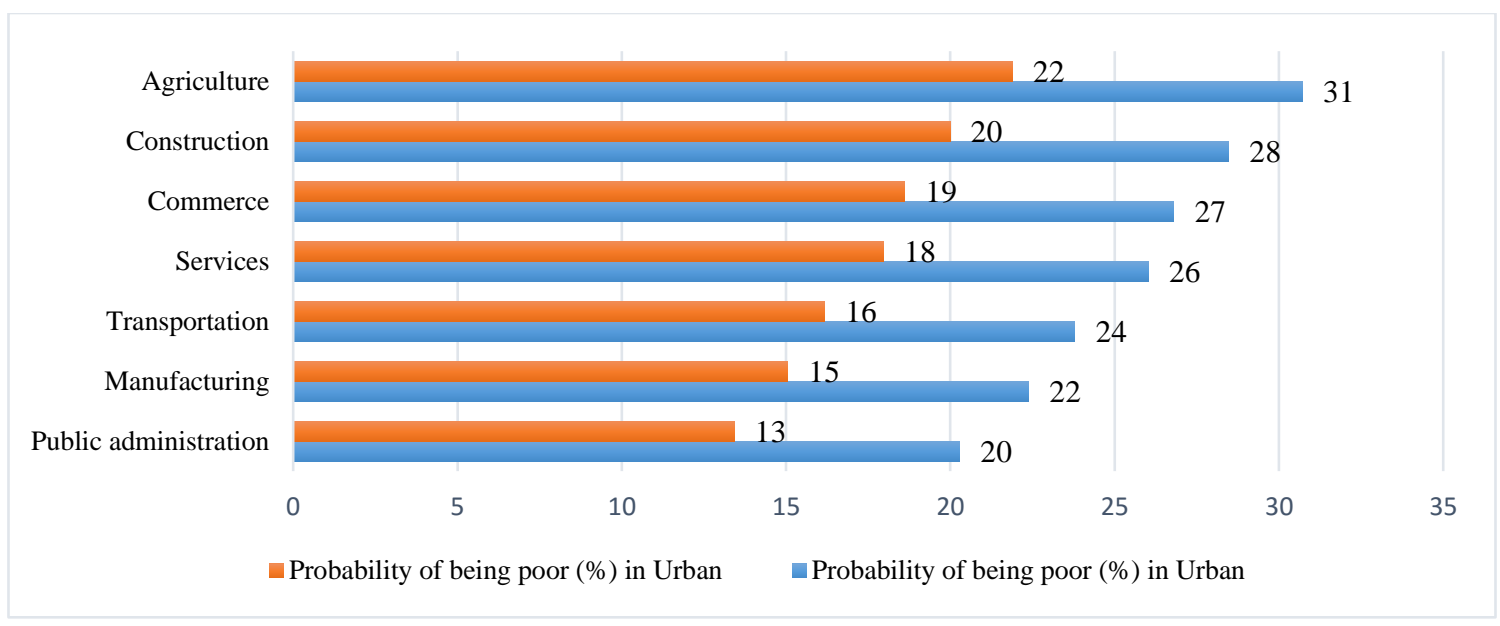

Source: Table D-1, Appendix D.

Furthermore, the results also revealed that households whose main source of income is their own business are the least probable to face poverty in rural and urban areas with $21.13 \%$ and $14.21 \%$ probabilities respectively. However, rural areas' residents have higher chance to be poor. Moreover, households whose income coming from remittances or salaries and wages suffer almost equally from poverty incidence.

In order to assess the impact of the HH educational level on the probability of falling into poverty, we vary the head's level of education, keeping all other determinants at the sample mean. It is observed that there is an obvious elevated decrease in the risk of poverty for households headed by individuals with higher levels of education, in contrast with a high poverty hazard for households headed by illiterate persons as illustrated in Figure 12. In urban areas, the probability of being poor is about $22 \%$ lower for households with university-educated heads than those with illiterate heads, about $19 \%$ lower for those headed by secondary school graduates, almost $15 \%$ lower for households headed by professional education holders and $9 \%$ lower for households headed by persons with primary education. On the other hand, rural areas households headed by illiterate persons are almost $27 \%$ higher anticipated to be poor than those headed by university degree holders, 23\% higher than secondary school graduate headed households, and about $17 \%$ and $10 \%$ higher than households headed by professional education and primary school individuals respectively. It was also observed that on all education levels, male-headed households are more inclined to be poor than their female counterparts. Hence, poverty reduction implies increasing educational level of households' heads by means of some basic education-enforcing policies.

Figure 12: The Predicted Effect of Education on the Poverty in Egypt 


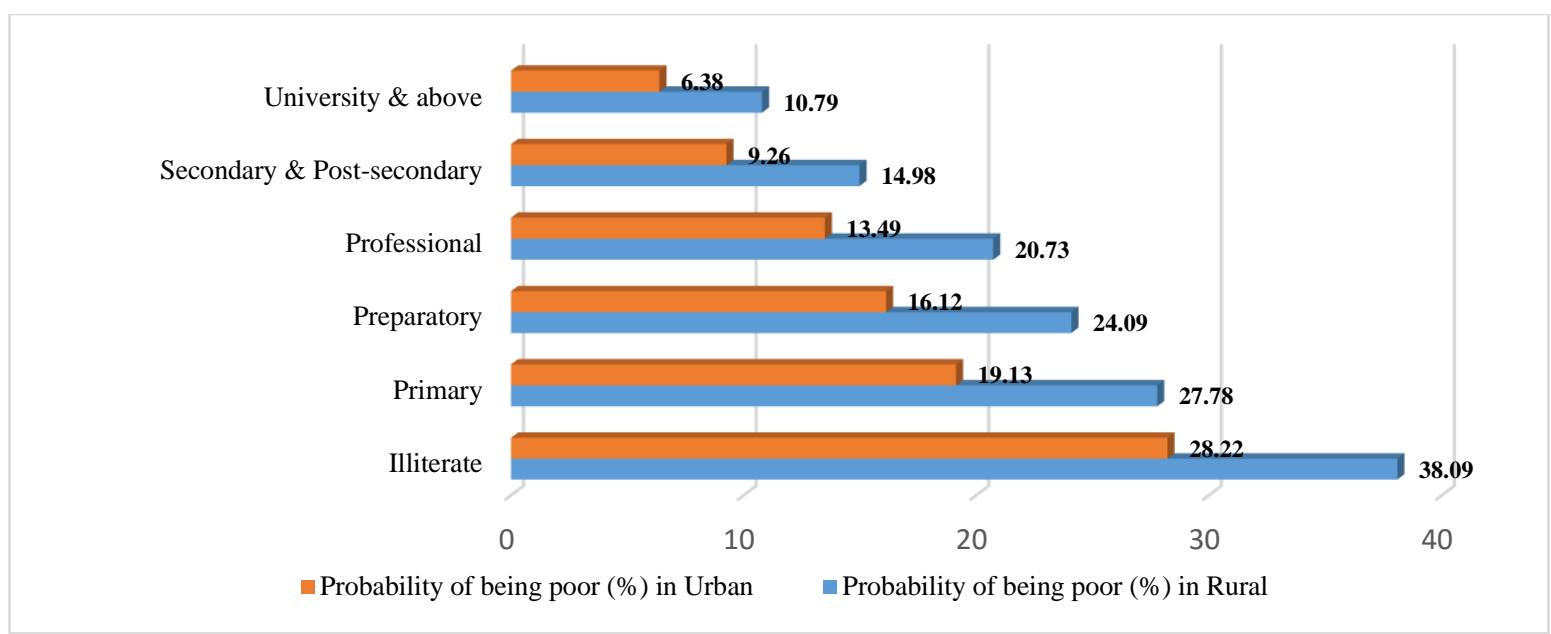

Source: Table D-1, Appendix D.

\section{Discussion and Conclusion}

As shown by poverty profile accompanied by the models' outcomes discussed in previous sections, living conditions in Egypt are deteriorating over time. The models and simulation analysis contribute to figuring out the main determinants to be targeted to reduce poverty and help improve and enhance prosperity levels.

The results of the models are consistent with the literature, the poverty profile analysis and each other, with some exceptions. The results indicates that rural area residents' living conditions are getting worse. Therefore, policies targeting the development of rural areas are essential to fight poverty. In addition, family size presents a harmful factor on household's wellbeing and poverty status in the sense that large sized households suffer more from poverty as they face insufficient financing and other resources. Similarly, large families must endure the problem of crowding in the apartment, leading to bad health conditions.

The results also disclosed that female-headed households suffer less from poverty than maleheaded ones. Moreover, the two models disclosed that divorced heads tend to have families with lower consumption than married ones and hence inferior standard of living. In other words, households headed by divorced individuals are more likely to be poor than those headed by married heads. As a result, there must be social programs to help divorced heads and provide opportunities for them to combat poverty. Not to mention, the results provide that households with pensioner spouses had lower consumption and more chance of falling into poverty in 2015 than other households with employed spouses, compared to previous years. As far as the industry of employment of $\mathrm{HH}$ is concerned, the results uncover that heads working in agriculture sector were better off than heads working in services in 2011, but this turned to be the inverse in 2015. This may be due to deterioration in the agriculture sector, which implicates that policy intervention is necessary to improve and develop the agriculture sector. According to the results, number of earners per household helps lessen the probability of falling into poverty - that is, as the number of households' earners increases - the probability of being poor decreases. However, poverty profile results show that a high number of earners is associated with high poverty measures, which is opposed to the results of the two regression models. This could be explained by the fact that the poverty profile does not isolate the effect of other factors on poverty measures and does not indicate 
any causality. Therefore, more poverty incidence leads to more number of earners per household. Moreover, high dependency ratio could enforce the negative effect of large family sizes with a small number of earners.

Out of all sources of income of $\mathrm{HH}$, household businesses exhibited the lowest likelihood of being poor in 2015 opposed to its negative effect on prosperity levels in previous years, which implies that private business is getting better and helps lessen poverty rates. Polices devoted to the improvement of private businesses and encouragement of entrepreneurs will help improve living conditions and reduce poverty. In addition, higher medical expenditures contribute to increase consumption expenditures as well as reduce poverty probability.

Educational level of $\mathrm{HH}$ is one of the main factors that contributes to escaping poverty and enhancing standard of living. The poverty profile, as well as two employed regression techniques, support that by illustrating that heads with university and above degrees have the lowest eventuality of suffering from poverty and have the highest consumption expenditures level over other educational degrees. Furthermore, the family that suffers the most from poverty incidence is the one headed by an illiterate head.

The simulation results produced some potential policies and recommendations that should help attack poverty and improve households' well-being. Birth control and family planning in urban and rural areas are of a high importance to reducing and slowing population growth rate. For instance, the results revealed that in 2015, an extra family member increased the probability of being poor at all levels of family size, however, an extra person had a higher influence in larger households. Additionally, family size had a greater effect in rural areas than urban ones. To illustrate, reducing family size in rural and urban areas by half results in an approximately $45 \%$ decrease in the probability of being poor on average. This necessitates the need for some policies to encourage lessening number of births, and to promote family planning programs.

Moreover, females at rural areas are more probable to have poor families compared to urban areas, which is why they need women-empowerment policies as well as cash transfers directed to women who care for children. It was also found that households headed by divorced individuals suffer the most from poverty incidence. As a result, those households shall be better off with policies that provide their heads with employment opportunities and access to labor force. In addition, serious policies targeting pensioners are needed as they are the most susceptible group to poverty.

Concerning heads of households' working industry, in both rural and urban areas, households with heads working in the agriculture sector were the highest in facing the risk of being poor among other households, with about $31 \%$ and $22 \%$ probability of being poor in rural and urban areas respectively. Therefore, development actions in agriculture sector are of paramount importance to help pull many families out of poverty. This can be done through promoting investment towards agro-business. On average, a $\mathrm{HH}$ working in any industry in a rural area has a $7.8 \%$ more probability of being poor than his or her urban counterpart. Accordingly, targeting rural areas' industries for economic development is fundamental.

As mentioned earlier, illiterate heads and heads with primary and preparatory educational levels are the most vulnerable to poverty. Moreover, the enhancement of educational attainment of $\mathrm{HH}$ from being an illiterate to having primary degree will contribute to a reduction of likelihood of falling into poverty by $9.7 \%$ on average. As a result, it is recommended to make early stages of education mandatory to reduce poverty. As well as public education improvement and reduction in 
the disparities in access and quality of basic education among different regions which is considered substantial government reform. Agricultural education should also be reformed to better supply qualified labor helping redress agriculture sector. 


\section{References}

Achia, T.N., A. Wangombe, and N. Khadioli, 2010. A Logistic Regression Model to Identify Key Determinants of Poverty Using Demographic and Health Survey Data. European Journal of Social Sciences, 13 (1), pp. 38-45.

Akerele, D. and S.A. Adewuyi, 2011. Analysis of Poverty Profiles and Socioeconomic Determinants of Welfare Among Urban Households of Ekiti State, Nigeria. Current Research Journal of Social Sciences, 3 (1), pp. 1-7.

ALL, J., 2005. Poverty Manual. Revision of August, 8, p. 2005.

Allison, P. D., 2009. Fixed Effects Regression Models (Vol. 160). SAGE publications.

Baulch, B. and N. McCulloch, 1998. Being Poor and Becoming Poor: Poverty Status and Poverty Transitions in Rural Pakistan.

Booysen, F., S. Van Der Berg, R. Burger, M. Von Maltitz and G. Du Rand, 2008. Using An Asset Index to Assess Trends in Poverty in Seven Sub-Saharan African Countries. World Development, 36 (6), pp. 1113-1130.

Cortinovis, I., V. Vella and J. Ndiku, 1993. Construction of A Socio-Economic Index to Facilitate Analysis of Health Data in Developing Countries. Social science and medicine, 36 (8), pp. 10871097.

Dartanto, T. and Nurkholis, 2013. The Determinants of Poverty Dynamics in Indonesia: Evidence From Panel Data. Bulletin of Indonesian Economic Studies, 49 (1), pp. 61-84.

Datt, G. and D. Jolliffe, 1999. Determinants of Poverty in Egypt: 1997. Food Consumption and Nutrition Division Discussion Paper, 75.

Datt, G. and D. Jolliffe, 2005. Poverty in Egypt: Modeling and Policy Simulations. Economic Development and Cultural Change, 53 (2), pp. 327-346.

Datt, G., D. Jolliffe and M. Sharma, 1998. A Profile of Poverty in Egypt: 1997. Food Consumption and Nutrition Division Discussion Paper, 49.

Deininger, K. and L. Squire, 1996. A New Data Set Measuring Income Inequality. The World Bank Economic Review, 10 (3), pp. 565-591.

Edoumiekumo, S.G., T.M. Karimo and S.S. Tombofa, 2014. Income Poverty in Nigeria: Incidence, Gap, Severity and Correlates. American Journal of Humanities and Social Sciences, 2 (1), pp. 1-9.

El-Laithy, H., 2001, January. The Gender Dimensions of Poverty in Egypt. Economic Research Forum for the Arab Countries, Iran and Turkey.

El-Laithy, H., 2011. The ADCR 2011: Poverty in Egypt (2009). Arab Development Challenges Report, UNDP Google Scholar.

El-Laithy, H., M. Lokshin and A. Banerji, 2003. Poverty and Economic Growth in Egypt, 19952000 . 
Foster, J., J. Greer and E. Thorbecke, 1984. A Class of Decomposable Poverty Measures. Econometrica: Journal of The Econometric Society, pp. 761-766.

Geda, A., N. De Jong, G. Mwabu and M. Kimenyi, 2001. Determinants of Poverty in Kenya: A Household Level Analysis. ISS Working Paper Series/General Series, 347, pp. 1-20.

Glewwe, P., 1991. Investigating the Determinants of Household Welfare in Côte d'Ivoire. Journal of Development Economics, 35 (2), pp. 307-337.

Gounder, N., 2013. Correlates of poverty in Fiji: An Analysis of Individual, Household and Community Factors Related to Poverty. International Journal of Social Economics, 40 (10), pp. 923-938.

Gujarati, D.N. and Porter, D.C., 2009. Basic Econometrics. 5th.

Habyarimana, J.B., 2015. Determinants of Household Food Insecurity in Developing Countries Evidences from a Probit Model for the Case of Rural Households in Rwanda. Sustainable Agriculture Research, 4 (2), p. 78.

Iwasaki, E. and H. El-Laithy, 2013. Estimation of Poverty in Greater Cairo: Case Study of Three 'Unplanned'Areas. African Development Review, 25 (2), pp. 173-188.

Kabubo-Mariara, J. and T.W. Kiriti, 2002. Structural Adjustment, Poverty and Economic Growth: An Analysis for Kenya.

Lanjouw, P. and M. Ravallion, 1995. Poverty and Household Size. The Economic Journal, pp. 1415-1434.

Lekobane, K.R. and T.B. Seleka, 2017. Determinants of Household Welfare and Poverty in Botswana, 2002/2003 and 2009/2010. Journal of Poverty, 21 (1), pp. 42-60.

Litchfield, J. and T. McGregor, 2008. Poverty in Kagera, Tanzania: Characteristics, Causes and Constraints. Poverty Research Unit at Sussex, University of Sussex.

Mok, T.Y., C. Gan and A. Sanyal, 2007. The Determinants of Urban Household Poverty in Malaysia. Journal of Social Sciences, 3 (4), pp. 190-196.

Mukherjee, S. and T. Benson, 2003. The Determinants of Poverty in Malawi, 1998. World Development, 31 (2), pp. 339-358.

OAMDI, 2017. Harmonized Household Income and Expenditure Surveys (HHIES), http://www.erf.org.eg/cms.php?id=erfdataportal.

Version 2.0 of Licensed Data Files; HIECS 2015 - Central Agency for Public Mobilization and Statistics (CAPMAS). Egypt: Economic Research Forum (ERF).

OAMDI, 2014. Harmonized Household Income and Expenditure Surveys (HHIES), http://www.erf.org.eg/cms.php?id=erfdataportal.

Version 2.0 of Licensed Data Files; HIECS 2012/2013 - Central Agency for Public Mobilization and Statistics (CAPMAS). Egypt: Economic Research Forum (ERF). 
OAMDI, 2014. Harmonized Household Income and Expenditure Surveys (HHIES), http://www.erf.org.eg/cms.php?id=erfdataportal.

Version 2.0 of Licensed Data Files; HIECS 2010/2011 - Central Agency for Public Mobilization and Statistics (CAPMAS). Egypt: Economic Research Forum (ERF).

Rahman, M.A., 2013. Household Characteristics and Poverty: A Logistic Regression Analysis. The Journal of Developing Areas, 47 (1), pp. 303-317.

Rusnak, Z., 2012. Logistic Regression Model In Poverty Analyses. Econometrics/Ekonometria, (35).

Sahn, D.E. and D.C. Stifel, 2000. Poverty Comparisons Over Time and Across Countries in Africa. World development, 28 (12), pp. 2123-2155.

Serumaga-Zake, P. and W. Naudé, 2002. The Determinants of Rural and Urban Household Poverty in the North West Province of South Africa. Development Southern Africa,19 (4), pp. 561-572.

Shete, M., 2010. Magnitude and Determinants of Rural Poverty in Zeghe Peninsula, Ethiopia. Journal of Poverty, 14 (3), pp. 308-328.

Sikander, M.U. and M. Ahmed, 2008. "Household Determinants of Poverty in Punjab: A Logistic Regression Analysis of MICS (2003-04) Data Set". In 8th Global Conference on Business and Economics.

World Bank, 2018. GINI Inderx ( World Bank Estimates).

[Online]

Available at: https://data.worldbank.org/indicator/SI.POV.GINI

[Accessed 11 June 2018]. 


\section{Appendix A}

Table A-1: Egyptian Regions Classification

\begin{tabular}{|c|c|c|c|c|c|c|}
\hline Urban & $\begin{array}{c}\text { Lower } \\
\text { Urban }\end{array}$ & $\begin{array}{c}\text { Lower } \\
\text { Rural }\end{array}$ & $\begin{array}{c}\text { Upper } \\
\text { Urban }\end{array}$ & $\begin{array}{c}\text { Upper } \\
\text { Rural }\end{array}$ & $\begin{array}{c}\text { Border } \\
\text { Urban }\end{array}$ & $\begin{array}{c}\text { Border } \\
\text { Rural }\end{array}$ \\
\hline Cairo & Damietta & Damietta & Giza & Giza & Red Sea & Red Sea \\
\hline Alexandria & Dakahlia & Dakahlia & Beni Suef & Beni Suef & New Valley & New Valley \\
\hline Port Said & Al Sharkia & Al Sharkia & Faiyum & Faiyum & Matrouh & Matrouh \\
\hline Suez & Qaliobeya & Qaliubiya & Minya & Minya & North Sinai & North Sinai \\
\hline & $\begin{array}{c}\text { Kafr- } \\
\text { Elsheikh }\end{array}$ & $\begin{array}{c}\text { Kafr- } \\
\text { Elsheikh }\end{array}$ & Asyut & Asyut & South Sinai & South Sinai \\
\hline & Gharbia & Gharbia & Suhag & Suhag & & \\
\hline & Menofiya & Menofiya & Qena & Qena & & \\
\hline & Beheira & Beheira & Aswan & Aswan & & \\
\hline & Ismailia & Ismailia & Luxor & Luxor & & \\
\hline
\end{tabular}

Table A-2: Poverty Measurements by Household Size (2011, 2013, 2015)

\begin{tabular}{|c|c|c|c|c|c|c|c|c|c|c|c|c|c|c|c|c|c|c|}
\hline \multicolumn{19}{|c|}{ National } \\
\hline & \multicolumn{3}{|c|}{1} & \multicolumn{3}{|c|}{2} & \multicolumn{3}{|c|}{3} & \multicolumn{3}{|c|}{4} & \multicolumn{3}{|c|}{5} & \multicolumn{3}{|c|}{6} \\
\hline & 2011 & 2013 & 2015 & 2011 & 2013 & 2015 & 2011 & 2013 & 2015 & 2011 & 2013 & 2015 & 2011 & 2013 & 2015 & 2011 & 2013 & 2015 \\
\hline$P_{0}(\%)$ & 1.40 & 1.21 & 0.41 & 1.80 & 2.48 & 1.77 & 5.33 & 7.44 & 5.85 & 12.20 & 15.66 & 13.64 & 20.61 & 24.16 & 26.25 & 33.68 & 35.95 & 41.50 \\
\hline$P_{1}(\%)$ & 0.24 & 0.14 & 0.09 & 0.35 & 0.25 & 0.24 & 0.82 & 0.91 & 0.77 & 2.04 & 2.64 & 1.96 & 3.48 & 4.29 & 4.59 & 6.59 & 6.48 & 8.08 \\
\hline$P_{2}(\%)$ & 0.05 & 0.03 & 0.10 & 0.11 & 0.00 & 0.28 & 0.22 & 0.22 & 0.88 & 0.52 & 0.71 & 2.25 & 0.97 & 1.21 & 5.42 & 1.94 & 1.93 & 9.56 \\
\hline \multicolumn{19}{|c|}{ Rural } \\
\hline & \multicolumn{3}{|c|}{1} & \multicolumn{3}{|c|}{2} & \multicolumn{3}{|c|}{3} & \multicolumn{3}{|c|}{4} & \multicolumn{3}{|c|}{5} & \multicolumn{3}{|c|}{6} \\
\hline & 2011 & 2013 & 2015 & 2011 & 2013 & 2015 & 2011 & 2013 & 2015 & 2011 & 2013 & 2015 & 2011 & 2013 & 2015 & 2011 & 2013 & 2015 \\
\hline$P_{0}(\%)$ & 2.04 & 1.93 & 0.28 & 2.70 & 2.91 & 3.42 & 6.44 & 8.65 & 9.51 & 16.86 & 19.68 & 20.50 & 25.24 & 27.53 & 37.95 & 37.76 & 37.09 & 55.02 \\
\hline$P_{1}(\%)$ & 0.43 & 4.92 & 0.00 & 0.51 & 0.28 & 0.12 & 0.98 & 1.20 & 0.45 & 2.89 & 3.48 & 1.29 & 4.32 & 5.04 & 3.30 & 7.22 & 6.99 & 5.90 \\
\hline$P_{2}(\%)$ & 0.09 & 1.56 & 0.00 & 0.17 & 0.05 & 0.14 & 0.30 & 0.32 & 0.51 & 0.74 & 0.98 & 0.71 & 1.18 & 1.45 & 3.89 & 2.04 & 2.15 & 6.99 \\
\hline \multicolumn{19}{|c|}{ Urban } \\
\hline & \multicolumn{3}{|c|}{1} & \multicolumn{3}{|c|}{2} & \multicolumn{3}{|c|}{3} & \multicolumn{3}{|c|}{4} & \multicolumn{3}{|c|}{5} & \multicolumn{3}{|c|}{6} \\
\hline & 2011 & 2013 & 2015 & 2011 & 2013 & 2015 & 2011 & 2013 & 2015 & 2011 & 2013 & 2015 & 2011 & 2013 & 2015 & 2011 & 2013 & 2015 \\
\hline$P_{0}(\%)$ & 0.86 & 0.69 & 0.79 & 0.94 & 2.52 & 1.69 & 3.30 & 4.75 & 3.41 & 7.18 & 10.45 & 9.10 & 14.23 & 19.00 & 16.84 & 23.04 & 30.68 & 29.56 \\
\hline$P_{1}(\%)$ & 0.08 & 0.08 & 0.09 & 0.17 & 0.21 & 0.12 & 0.60 & 0.49 & 0.28 & 1.06 & 1.40 & 0.61 & 2.47 & 3.11 & 1.14 & 5.05 & 5.16 & 1.95 \\
\hline$P_{2}(\%)$ & 0.01 & 0.02 & 0.11 & 0.04 & 0.03 & 0.14 & 0.14 & 0.07 & 0.33 & 0.26 & 0.30 & 1.46 & 0.70 & 0.80 & 1.34 & 1.61 & 1.36 & 2.27 \\
\hline
\end{tabular}

Table A-3: Poverty Measurements by Age of Head of Household (2011, 2013, 2015)

\begin{tabular}{|c|c|c|c|c|c|c|c|c|c|c|c|c|c|c|c|c|c|c|}
\hline \multicolumn{19}{|c|}{ National } \\
\hline & \multicolumn{3}{|c|}{ less 20} & \multicolumn{3}{|c|}{$20-30$} & \multicolumn{3}{|c|}{$30-40$} & \multicolumn{3}{|c|}{$40-50$} & \multicolumn{3}{|c|}{$50-60$} & \multicolumn{3}{|c|}{ above 60} \\
\hline & 2010 & 2012 & 2015 & 2010 & 2012 & 2015 & 2010 & 2012 & 2015 & 2010 & 2012 & 2015 & 2010 & 2012 & 2015 & 2010 & 2012 & 2015 \\
\hline$P_{0}(\%)$ & 16.67 & 0.00 & 7.14 & 18.32 & 23.51 & 25.25 & 25.07 & 27.39 & 31.76 & 22.90 & 26.59 & 29.19 & 14.49 & 15.71 & 15.62 & 12.35 & 12.61 & 12.83 \\
\hline$P_{1}(\%)$ & 6.94 & 0.00 & 2.24 & 3.09 & 4.76 & 4.74 & 4.97 & 5.25 & 6.43 & 4.75 & 5.20 & 5.85 & 2.79 & 2.91 & 3.07 & 2.41 & 2.33 & 2.55 \\
\hline$P_{2}(\%)$ & 2.89 & 0.00 & 0.70 & 0.81 & 1.50 & 1.37 & 1.49 & 1.60 & 1.93 & 1.51 & 1.65 & 1.73 & 0.81 & 0.87 & 0.92 & 0.69 & 0.67 & 0.77 \\
\hline \multicolumn{19}{|c|}{ Rural } \\
\hline
\end{tabular}




\begin{tabular}{|c|c|c|c|c|c|c|c|c|c|c|c|c|c|c|c|c|c|c|}
\hline & \multicolumn{3}{|c|}{ less 20} & \multicolumn{3}{|c|}{$20-30$} & \multicolumn{3}{|c|}{$30-40$} & \multicolumn{3}{|c|}{$40-50$} & \multicolumn{3}{|c|}{$50-60$} & \multicolumn{3}{|c|}{ above 60} \\
\hline & 2010 & 2012 & 2015 & 2010 & 2012 & 2015 & 2010 & 2012 & 2015 & 2010 & 2012 & 2015 & 2010 & 2012 & 2015 & 2010 & 2012 & 2015 \\
\hline$P_{0}(\%)$ & 0.00 & 0.00 & 16.67 & 21.10 & 26.35 & 30.60 & 30.87 & 30.48 & 37.17 & 28.24 & 30.75 & 36.64 & 18.65 & 19.22 & 21.40 & 17.82 & 16.47 & 16.35 \\
\hline$P_{1}(\%)$ & 0.00 & 0.00 & 5.01 & 3.60 & 5.23 & 5.58 & 6.19 & 6.21 & 7.86 & 5.94 & 6.41 & 7.32 & 3.66 & 3.59 & 4.18 & 3.48 & 3.11 & 3.24 \\
\hline$P_{2}(\%)$ & 0.00 & 0.00 & 1.51 & 0.94 & 1.60 & 1.61 & 1.85 & 1.94 & 2.41 & 1.84 & 2.10 & 2.19 & 1.09 & 1.11 & 1.23 & 1.03 & 0.91 & 0.94 \\
\hline \multicolumn{19}{|c|}{ Urban } \\
\hline & \multicolumn{3}{|c|}{ less 20} & \multicolumn{3}{|c|}{$20-30$} & \multicolumn{3}{|c|}{$30-40$} & \multicolumn{3}{|c|}{$40-50$} & \multicolumn{3}{|c|}{$50-60$} & \multicolumn{3}{|c|}{ above 60} \\
\hline & 2010 & 2012 & 2015 & 2010 & 2012 & 2015 & 2010 & 2012 & 2015 & 2010 & 2012 & 2015 & 2010 & 2012 & 2015 & 2010 & 2012 & 2015 \\
\hline$P_{0}(\%)$ & 25.00 & 0.00 & 0.00 & 12.70 & 16.46 & 13.24 & 16.55 & 22.60 & 20.76 & 17.08 & 21.40 & 19.27 & 10.56 & 11.97 & 9.04 & 7.31 & 8.77 & 9.11 \\
\hline$P_{2}(\%)$ & 4.69 & 0.00 & 0.00 & 0.37 & 0.85 & 0.69 & 0.77 & 0.85 & 0.83 & 1.06 & 0.94 & 0.97 & 0.52 & 0.56 & 0.48 & 0.32 & 0.37 & 0.56 \\
\hline
\end{tabular}

Table A-4: Poverty Measurements by Gender of Head of Household (2011, 2013, 2015)

\begin{tabular}{|c|c|c|c|c|c|c|c|c|c|c|c|c|c|c|c|c|c|c|}
\hline & \multicolumn{6}{|c|}{ National } & \multicolumn{7}{|c|}{ Rural } & \multicolumn{5}{|c|}{ Urban } \\
\hline & \multicolumn{3}{|c|}{ Male } & \multicolumn{3}{|c|}{ Female } & \multicolumn{3}{|c|}{ Male } & \multicolumn{3}{|c|}{ Female } & & \multicolumn{2}{|c|}{ Male } & \multicolumn{3}{|c|}{ Female } \\
\hline & 2011 & 2013 & 2015 & 2011 & 2013 & 2015 & 2011 & 2013 & 2015 & 2011 & 2013 & 2015 & 2011 & 2013 & 2015 & 2011 & 2013 & 2015 \\
\hline$P_{0}(\%)$ & 19.74 & 22.19 & 23.60 & 14.27 & 14.71 & 15.16 & 25.18 & 26.33 & 30.23 & 18.50 & 18.18 & 19.38 & 11.91 & 16.95 & 14.78 & 8.49 & 10.51 & 8.96 \\
\hline$P_{1}(\%)$ & 3.92 & 4.24 & 4.73 & 2.63 & 2.90 & 2.93 & 5.04 & 5.24 & 6.13 & 3.49 & 3.76 & 3.71 & 2.35 & 2.65 & 2.59 & 1.54 & 1.64 & 1.76 \\
\hline$P_{2}(\%)$ & 1.18 & 1.29 & 1.40 & 0.76 & 0.91 & 0.90 & 1.51 & 1.63 & 1.83 & 1.01 & 1.23 & 1.11 & 0.70 & 0.73 & 0.72 & 0.44 & 0.44 & 0.58 \\
\hline
\end{tabular}

Table A-5: Poverty Measurements by Marital Status of Head of Household (2011, 2013, 2015)

\begin{tabular}{|c|c|c|c|c|c|c|c|c|c|c|c|c|}
\hline \multicolumn{13}{|c|}{ National } \\
\hline & \multicolumn{3}{|c|}{ Married } & \multicolumn{3}{|c|}{ Divorced } & \multicolumn{3}{|c|}{ Widow } & \multicolumn{3}{|c|}{ Never Married } \\
\hline & 2011 & 2013 & 2015 & 2011 & 2013 & 2015 & 2011 & 2013 & 2015 & 2011 & 2013 & 2015 \\
\hline$P_{0}(\%)$ & 20.42 & 23.03 & 24.27 & 13.64 & 14.78 & 12.79 & 11.47 & 10.86 & 12.35 & 5.56 & 7.58 & 5.33 \\
\hline$P_{1}(\%)$ & 4.05 & 4.40 & 4.83 & 2.28 & 3.17 & 2.09 & 2.12 & 2.16 & 2.43 & 0.91 & 1.38 & 0.98 \\
\hline $\mathbf{P}_{2}(\%)$ & 1.22 & 1.34 & 1.42 & 0.51 & 1.17 & 0.66 & 0.61 & 0.69 & 0.78 & 0.25 & 0.31 & 0.22 \\
\hline \multicolumn{13}{|c|}{ Rural } \\
\hline & \multicolumn{3}{|c|}{ Married } & \multicolumn{3}{|c|}{ Divorced } & \multicolumn{3}{|c|}{ Widow } & \multicolumn{3}{|c|}{ Never Married } \\
\hline & 2011 & 2013 & 2015 & 2011 & 2013 & 2015 & 2011 & 2013 & 2015 & 2011 & 2013 & 2015 \\
\hline$P_{0}(\%)$ & 25.62 & 26.66 & 30.53 & 29.17 & 20.51 & 14.63 & 15.00 & 14.07 & 16.22 & 5.88 & 18.60 & 10.17 \\
\hline$P_{1}(\%)$ & 5.12 & 5.30 & 6.13 & 4.82 & 3.82 & 2.76 & 2.78 & 3.04 & 3.13 & 1.48 & 3.56 & 1.96 \\
\hline$P_{2}(\%)$ & 1.54 & 1.65 & 1.82 & 1.04 & 1.37 & 0.87 & 0.80 & 1.05 & 0.98 & 0.44 & 0.77 & 0.43 \\
\hline \multicolumn{13}{|c|}{ Urban } \\
\hline & \multicolumn{3}{|c|}{ Married } & \multicolumn{3}{|c|}{ Divorced } & \multicolumn{3}{|c|}{ Widow } & \multicolumn{3}{|c|}{ Never Married } \\
\hline & 2011 & 2013 & 2015 & 2011 & 2013 & 2015 & 2011 & 2013 & 2015 & 2011 & 2013 & 2015 \\
\hline$P_{0}(\%)$ & 12.40 & 18.06 & 15.63 & 7.81 & 19.74 & 10.95 & 7.21 & 11.69 & 7.50 & 4.50 & 2.22 & 1.82 \\
\hline$P_{1}(\%)$ & 2.41 & 2.79 & 2.69 & 1.32 & 2.95 & 1.76 & 1.44 & 1.23 & 1.54 & 0.51 & 0.15 & 0.40 \\
\hline$P_{2}(\%)$ & 0.71 & 0.77 & 0.75 & 0.31 & 1.12 & 0.55 & 0.42 & 0.30 & 0.52 & 0.11 & 0.02 & 0.09 \\
\hline
\end{tabular}

Table A-6: Poverty Measurements by Status of Employment of Head of Household (2011, 2013, 2015)

\begin{tabular}{|c|c|c|c|c|c|c|c|c|c|c|c|c|}
\hline \multicolumn{13}{|c|}{ National } \\
\hline & \multicolumn{3}{|c|}{ Contributing } & \multicolumn{3}{|c|}{ Employee } & \multicolumn{3}{|c|}{ Employer } & \multicolumn{3}{|c|}{ Own Account } \\
\hline & 2011 & 2013 & 2015 & 2011 & 2013 & 2015 & 2011 & 2013 & 2015 & 2011 & 2013 & 2015 \\
\hline$P_{0}(\%)$ & 7.69 & 0.00 & 31.58 & 20.78 & 23.10 & 25.06 & 17.81 & 22.09 & 23.87 & 24.20 & 23.92 & 26.18 \\
\hline$P_{1}(\%)$ & 0.75 & 0.00 & 57.26 & 4.10 & 4.50 & 4.95 & 3.33 & 3.83 & 4.60 & 4.84 & 4.81 & 5.58 \\
\hline$P_{2}(\%)$ & 0.07 & 0.00 & 6.56 & 1.23 & 1.40 & 5.95 & 0.92 & 1.05 & 5.53 & 1.49 & 1.55 & 6.75 \\
\hline \multicolumn{13}{|c|}{ Rural } \\
\hline & \multicolumn{3}{|c|}{ Contributing } & \multicolumn{3}{|c|}{ Employee } & \multicolumn{3}{|c|}{ Employer } & \multicolumn{3}{|c|}{ Own Account } \\
\hline
\end{tabular}




\begin{tabular}{|c|c|c|c|c|c|c|c|c|c|c|c|c|}
\hline & 2011 & 2013 & 2015 & 2011 & 2013 & 2015 & 2011 & 2013 & 2015 & 2011 & 2013 & 2015 \\
\hline$P_{0}(\%)$ & 9.09 & 0.00 & 30.77 & 26.67 & 27.41 & 32.70 & 20.72 & 23.03 & 26.96 & 20.00 & 29.95 & 32.74 \\
\hline $\mathbf{P}_{1}(\%)$ & 0.70 & 0.00 & 4.26 & 5.24 & 5.67 & 3.67 & 3.93 & 3.99 & 3.77 & 5.84 & 6.23 & 3.90 \\
\hline$P_{2}(\%)$ & 0.05 & 0.00 & 4.93 & 1.57 & 1.81 & 4.42 & 1.06 & 1.08 & 4.54 & 1.81 & 2.09 & 4.71 \\
\hline \multicolumn{13}{|c|}{ Urban } \\
\hline & \multicolumn{3}{|c|}{ Contributing } & \multicolumn{3}{|c|}{ Employee } & \multicolumn{4}{|c|}{ Employer } & \multicolumn{2}{|c|}{ Dwn Account } \\
\hline & 2011 & 2013 & 2015 & 2011 & 2013 & 2015 & 2011 & 2013 & 2015 & 2011 & 2013 & 2015 \\
\hline$P_{0}(\%)$ & 0.00 & 0.00 & 33.33 & 12.38 & 16.41 & 15.40 & 7.97 & 12.50 & 13.62 & 19.40 & 18.64 & 17.88 \\
\hline$P_{1}(\%)$ & 0.00 & 0.00 & 1.39 & 2.54 & 2.81 & 1.14 & 1.26 & 2.06 & 0.62 & 3.51 & 3.24 & 1.54 \\
\hline$P_{2}(\%)$ & 0.00 & 0.00 & 1.50 & 0.76 & 0.77 & 1.35 & 0.36 & 0.57 & 0.72 & 1.02 & 3.24 & 1.87 \\
\hline
\end{tabular}

Table A-7: Poverty Measurements by Status of Employment of Spouse $(2011,2013,2015)$

\begin{tabular}{|c|c|c|c|c|c|c|c|c|c|c|c|c|c|c|c|c|c|c|}
\hline & \multicolumn{6}{|c|}{ National } & \multicolumn{6}{|c|}{ Rural } & \multicolumn{6}{|c|}{ Urban } \\
\hline & \multicolumn{3}{|c|}{ Working } & \multicolumn{3}{|c|}{ Not working } & \multicolumn{3}{|c|}{ Working } & \multicolumn{3}{|c|}{ Not working } & \multicolumn{3}{|c|}{ Working } & \multicolumn{3}{|c|}{ Not working } \\
\hline & 2011 & 2013 & 2015 & 2011 & 2013 & 2015 & 2011 & 2013 & 2015 & 2011 & 2013 & 2015 & 2011 & 2013 & 2015 & 2011 & 2013 & 2015 \\
\hline$P_{0}(\%)$ & 22.07 & 21.16 & 20.90 & 17.34 & 20.76 & 25.48 & 24.56 & 24.72 & 27.80 & 23.77 & 24.97 & 31.68 & 10.20 & 11.02 & 9.59 & 11.57 & 15.20 & 17.08 \\
\hline$P_{1}(\%)$ & 3.50 & 3.72 & 4.32 & 4.15 & 4.08 & 5.06 & 4.89 & 4.17 & 3.56 & 4.65 & 5.29 & 3.63 & 1.80 & 2.00 & 0.59 & 2.30 & 2.57 & 1.30 \\
\hline $\mathrm{P}_{2}(\%)$ & 1.08 & 1.03 & 52.50 & 1.18 & 1.29 & 6.06 & 1.52 & 1.10 & 4.33 & 1.31 & 1.74 & 4.34 & 0.47 & 0.61 & 0.69 & 0.69 & 0.69 & 1.54 \\
\hline
\end{tabular}

Table A-8: Poverty Measurements by Sector of Employment of Head of Household (2011, 2013, 2015)

\begin{tabular}{|c|c|c|c|c|c|c|c|c|c|c|c|c|c|c|c|}
\hline \multicolumn{16}{|c|}{ National } \\
\hline & \multicolumn{3}{|c|}{ Government } & \multicolumn{3}{|c|}{ Public Sector } & \multicolumn{3}{|c|}{ Private Sector } & \multicolumn{3}{|c|}{ Joint/Cooperative } & \multicolumn{3}{|c|}{ Others } \\
\hline & 2011 & 2013 & 2015 & 2011 & 2013 & 2015 & 2011 & 2013 & 2015 & 2011 & 2013 & 2015 & 2011 & 2013 & 2015 \\
\hline$P_{0}(\%)$ & 16.98 & 16.31 & 16.68 & 12.69 & 15.81 & 11.44 & 15.66 & 18.56 & 20.45 & 16.67 & 7.14 & 35.71 & 21.57 & 23.98 & 25.62 \\
\hline$P_{1}(\%)$ & 2.90 & 2.68 & 3.05 & 2.27 & 2.56 & 2.19 & 2.83 & 3.35 & 3.70 & 4.43 & 2.38 & 8.12 & 4.55 & 4.88 & 5.41 \\
\hline$P_{2}(\%)$ & 0.78 & 0.72 & 3.58 & 0.63 & 0.62 & 2.68 & 0.82 & 1.02 & 4.41 & 1.32 & 0.80 & 9.78 & 1.41 & 1.55 & 6.56 \\
\hline \multicolumn{16}{|c|}{ Rural } \\
\hline & \multicolumn{3}{|c|}{ Government } & \multicolumn{3}{|c|}{ Public Sector } & \multicolumn{3}{|c|}{ Private Sector } & \multicolumn{3}{|c|}{ Joint/Cooperative } & \multicolumn{3}{|c|}{ Others } \\
\hline & 2011 & 2013 & 2015 & 2011 & 2013 & 2015 & 2011 & 2013 & 2015 & 2011 & 2013 & 2015 & 2011 & 2013 & 2015 \\
\hline$P_{0}(\%)$ & 11.68 & 18.06 & 23.99 & 18.00 & 23.39 & 20.95 & 21.25 & 23.88 & 30.78 & 27.27 & 0.00 & 47.37 & 26.30 & 27.61 & 35.44 \\
\hline$P_{1}(\%)$ & 3.34 & 3.05 & 2.23 & 3.92 & 3.75 & 1.12 & 4.12 & 4.57 & 2.31 & 6.80 & 0.00 & 7.44 & 5.52 & 5.82 & 4.18 \\
\hline $\mathrm{P}_{2}(\%)$ & 0.85 & 0.82 & 2.62 & 1.18 & 0.96 & 1.34 & 1.22 & 1.42 & 2.76 & 1.94 & 0.00 & 8.96 & 1.70 & 1.88 & 5.06 \\
\hline \multicolumn{16}{|c|}{ Urban } \\
\hline & \multicolumn{3}{|c|}{ Government } & \multicolumn{3}{|c|}{ Public Sector } & \multicolumn{3}{|c|}{ Private Sector } & \multicolumn{3}{|c|}{ Joint/Cooperative } & \multicolumn{3}{|c|}{ Others } \\
\hline & 2011 & 2013 & 2015 & 2011 & 2013 & 2015 & 2011 & 2013 & 2015 & 2011 & 2013 & 2015 & 2011 & 2013 & 2015 \\
\hline $\mathrm{P}_{0}(\%)$ & 10.24 & 12.18 & 9.99 & 7.74 & 8.53 & 7.89 & 11.09 & 15.18 & 15.13 & 0.00 & 11.11 & 11.11 & 12.37 & 15.40 & 14.91 \\
\hline$P_{1}(\%)$ & 2.06 & 1.97 & 0.71 & 1.25 & 1.15 & 1.05 & 1.95 & 2.58 & 1.36 & 0.00 & 3.99 & 0.32 & 2.59 & 2.70 & 1.05 \\
\hline$P_{2}(\%)$ & 0.54 & 0.51 & 0.84 & 0.28 & 0.20 & 1.33 & 0.54 & 0.74 & 1.60 & 0.00 & 1.43 & 0.34 & 0.80 & 0.73 & 1.27 \\
\hline
\end{tabular}

Table A-9: Poverty Measurements by Number of Earners per Household (2011, 2013, 2015)

\begin{tabular}{|c|c|c|c|c|c|c|c|c|c|c|c|c|c|c|c|c|c|c|}
\hline \multicolumn{19}{|c|}{ National } \\
\hline & \multicolumn{3}{|c|}{1} & \multicolumn{3}{|c|}{2} & \multicolumn{3}{|c|}{3} & \multicolumn{3}{|c|}{4} & \multicolumn{3}{|c|}{5} & \multicolumn{3}{|c|}{6} \\
\hline & 2011 & 2013 & 2015 & 2011 & 2013 & 2015 & 2011 & 2013 & 2015 & 2011 & 2013 & 2015 & 2011 & 2013 & 2015 & 2011 & 2013 & 2015 \\
\hline $\mathbf{P}_{0}(\%)$ & 17.29 & 20.86 & 21.42 & 18.41 & 19.65 & 20.47 & 22.08 & 21.20 & 25.48 & 25.71 & 25.83 & 32.05 & 40.45 & 44.64 & 42.86 & 17.65 & 28.57 & 50.00 \\
\hline
\end{tabular}




\begin{tabular}{|c|c|c|c|c|c|c|c|c|c|c|c|c|c|c|c|c|c|c|}
\hline$P_{1}(\%)$ & 3.44 & 3.99 & 4.22 & 3.69 & 3.82 & 4.09 & 4.22 & 3.87 & 5.12 & 4.92 & 5.67 & 6.77 & 6.56 & 6.93 & 9.34 & 1.11 & 3.92 & 13.39 \\
\hline$P_{2}(\%)$ & 1.07 & 1.23 & 5.05 & 1.09 & 1.19 & 4.96 & 1.19 & 1.09 & 6.17 & 1.44 & 1.82 & 8.11 & 1.82 & 1.67 & 11.15 & 0.13 & 0.60 & 16.80 \\
\hline \multicolumn{19}{|c|}{ Rural } \\
\hline & \multicolumn{3}{|c|}{1} & \multicolumn{3}{|c|}{2} & \multicolumn{3}{|c|}{3} & \multicolumn{3}{|c|}{4} & \multicolumn{3}{|c|}{5} & \multicolumn{3}{|c|}{6} \\
\hline & 2011 & 2013 & 2015 & 2011 & 2013 & 2015 & 2011 & 2013 & 2015 & 2011 & 2013 & 2015 & 2011 & \begin{tabular}{|l|}
2013 \\
\end{tabular} & 2015 & 2011 & 2013 & 2015 \\
\hline$P_{0}(\%)$ & 21.51 & 24.19 & 26.50 & 24.55 & 25.44 & 27.53 & 28.34 & 24.78 & 33.66 & 31.98 & 31.06 & 43.28 & 50.00 & 36.36 & 48.28 & 11.11 & 25.00 & 66.67 \\
\hline$P_{1}(\%)$ & 4.36 & 4.92 & 3.05 & 4.90 & 5.03 & 2.98 & 5.51 & 4.48 & 3.93 & 6.12 & 7.13 & 4.75 & 8.44 & \begin{tabular}{|l|}
6.59 \\
\end{tabular} & 6.44 & 0.14 & 4.05 & 12.74 \\
\hline $\mathrm{P}_{2}(\%)$ & 1.36 & 1.56 & 3.66 & 1.41 & 1.59 & 3.61 & 1.58 & 1.23 & 4.76 & 1.79 & 2.43 & 5.67 & 2.33 & 1.60 & 7.58 & 0.00 & 0.65 & 15.91 \\
\hline \multicolumn{19}{|c|}{ Urban } \\
\hline & \multicolumn{3}{|c|}{1} & \multicolumn{3}{|c|}{2} & \multicolumn{3}{|c|}{3} & \multicolumn{3}{|c|}{4} & \multicolumn{3}{|c|}{5} & \multicolumn{3}{|c|}{6} \\
\hline & 2011 & 2013 & 2015 & 2011 & 2013 & 2015 & 2011 & 2013 & 2015 & 2011 & 2013 & 2015 & 2011 & 2013 & 2015 & 2011 & 2013 & 2015 \\
\hline$P_{0}(\%)$ & 10.77 & 14.71 & 14.22 & 11.26 & 12.76 & 11.66 & 12.60 & 15.60 & 14.16 & 16.08 & 19.44 & 19.51 & 3.70 & 34.78 & 36.36 & 12.50 & 33.33 & 25.00 \\
\hline$P_{1}(\%)$ & 2.15 & 2.42 & 1.05 & 2.20 & 2.28 & 0.98 & 2.22 & 2.70 & 1.04 & 3.15 & 3.61 & 1.82 & 0.11 & 7.01 & 2.70 & 2.14 & 4.13 & 0.04 \\
\hline$P_{2}(\%)$ & 0.56 & 0.64 & 1.25 & 0.67 & 0.66 & 1.19 & 0.54 & 0.77 & 1.21 & 0.90 & 0.94 & 2.20 & 0.00 & 1.73 & 3.31 & 0.37 & 0.51 & 0.04 \\
\hline
\end{tabular}

Table A-10: Poverty Measurements by Literacy of Head of Household (2011, 2013, 2015)

\begin{tabular}{|c|c|c|c|c|c|c|c|c|c|c|c|c|c|c|c|c|c|c|}
\hline & \multicolumn{6}{|c|}{ National } & \multicolumn{7}{|c|}{ Rural } & \multicolumn{5}{|c|}{ Urban } \\
\hline & \multicolumn{3}{|c|}{ Literate } & \multicolumn{3}{|c|}{ Illiterate } & \multicolumn{3}{|c|}{ Literate } & \multicolumn{3}{|c|}{ Illiterate } & & \multicolumn{2}{|c|}{ Literate } & \multicolumn{3}{|c|}{ Illiterate } \\
\hline & 2011 & 2013 & 2015 & 2011 & 2013 & 2015 & 2011 & 2013 & 2015 & 2011 & 2013 & 2015 & 2011 & 2013 & 2015 & 2011 & 2013 & 2015 \\
\hline$P_{0}(\%)$ & 14.57 & 16.88 & 18.89 & 27.45 & 28.97 & 30.61 & 9.26 & 12.20 & 25.90 & 17.89 & 21.54 & 33.02 & 19.74 & 20.47 & 11.66 & 30.85 & 31.58 & 22.83 \\
\hline $\mathrm{P}_{\mathbf{1}}(\%)$ & 2.69 & 2.91 & 3.53 & 5.84 & 6.22 & 6.73 & 3.66 & 3.71 & 2.48 & 6.51 & 6.88 & 5.17 & 1.68 & 1.99 & 0.96 & 3.90 & 3.99 & 1.35 \\
\hline$P_{2}(\%)$ & 0.76 & 0.82 & 4.19 & 1.85 & 2.06 & 8.25 & 1.04 & 1.05 & 2.95 & 2.02 & 2.33 & 3.63 & 0.46 & 0.53 & 1.13 & 1.27 & 1.14 & 1.65 \\
\hline
\end{tabular}

Table A-11: Poverty Measurements by Educational Level of Head of Household (2011, 2013, 2015)

\begin{tabular}{|l|c|c|c|c|c|c|c|c|c|c|c|c|c|c|c|c|c|c|c|}
\hline \multicolumn{10}{|c|}{ National } \\
\hline
\end{tabular}




\section{Appendix B}

Table B-1: Regression Models' Variables

\begin{tabular}{|c|c|c|}
\hline Name & Type & Specification \\
\hline \multicolumn{3}{|r|}{ Dependent Variables } \\
\hline Consumption expenditures & Continuous & Natural log of household's total consumption expenditures in EGP \\
\hline Poverty status & Dummy & Takes the value of 1 if the household is poor and 0 if the household is non poor \\
\hline \multicolumn{3}{|r|}{ Explanatory Variables } \\
\hline Residency & Dummy & $\begin{array}{l}\text { Indicates the region of residency of household: } \\
0 \rightarrow \text { Rural region } \\
1 \rightarrow \text { Urban region }\end{array}$ \\
\hline Household size & Continuous & Number of persons per household \\
\hline Number of Earners & Continuous & Number of earners per household \\
\hline Age of $\mathrm{HH}$ & Continuous & Age of $\mathrm{HH}$ \\
\hline Gender of HH & Dummy & $\begin{array}{l}0 \rightarrow \text { Female } \\
1 \rightarrow \text { Male }\end{array}$ \\
\hline Marital Status of $\mathbf{H H}$ & Dummy & $\begin{array}{l}0 \rightarrow \text { Never married } \\
1 \rightarrow \text { Married } \\
2 \rightarrow \text { Divorced } \\
3 \rightarrow \text { Widowed }\end{array}$ \\
\hline Employment status of $\mathbf{H H}$ & Dummy & $\begin{array}{l}0 \rightarrow \text { Unemployed } \\
1 \rightarrow \text { Employed } \\
2 \rightarrow \text { Pensioner }\end{array}$ \\
\hline $\begin{array}{c}\text { Employment status of first spouse of } \\
\text { HH }\end{array}$ & Dummy & $\begin{array}{l}0 \rightarrow \text { Unemployed } \\
1 \rightarrow \text { Employed } \\
2 \rightarrow \text { Pensioner }\end{array}$ \\
\hline Sector of employment of $\mathrm{HH}$ & Dummy & $\begin{array}{l}0 \rightarrow \text { Other Sectors } \\
1 \rightarrow \text { Public Sector } \\
2 \rightarrow \text { Private Sector }\end{array}$ \\
\hline Industry of employment of $\mathrm{HH}$ & Dummy & $\begin{array}{l}0 \rightarrow \text { Others } \\
1 \rightarrow \text { Agriculture } \\
2 \rightarrow \text { Commerce } \\
3 \rightarrow \text { Construction and Electricity } \\
4 \rightarrow \text { Manufacturing } \\
5 \rightarrow \text { Public Administration } \\
6 \rightarrow \text { Transportation } \\
7 \rightarrow \text { Services }\end{array}$ \\
\hline Educational level of $\mathrm{HH}$ & Continuous & $\begin{array}{l}0 \rightarrow \text { Illiterate } \\
1 \rightarrow \text { Primary } \\
2 \rightarrow \text { Preparatory } \\
3 \rightarrow \text { Secondary and Post-secondary } \\
4 \rightarrow \text { Professional } \\
5 \rightarrow \text { University and above }\end{array}$ \\
\hline Source of income of $\mathrm{HH}$ & Dummy & $\begin{array}{l}\text { Main income source of the household: } \\
0 \rightarrow \text { Other } \\
1 \rightarrow \text { Salaries and wages } \\
2 \rightarrow \text { Remittances } \\
3 \rightarrow \text { Household business }\end{array}$ \\
\hline Health expenditures & Continuous & Medical expenditures per person in EGP per year. \\
\hline
\end{tabular}




\begin{tabular}{|l|l|l|}
\hline Dependency ratio & Continuous & $\begin{array}{l}\text { The ratio of number of persons under the age of } 15 \text { and over the age of } 65 \text { to the number of } \\
\text { persons between, ages } 15-65 .\end{array}$ \\
\hline
\end{tabular}




\section{Appendix C}

Table C-1: Variance Inflation Factor (VIF)

\begin{tabular}{|c|c|c|c|c|c|c|}
\hline \multirow{2}{*}{ Variable } & \multicolumn{2}{|c|}{2015} & \multicolumn{2}{|c|}{2013} & \multicolumn{2}{|c|}{2011} \\
\hline & VIF & 1/VIF & VIF & 1/VIF & VIF & 1/VIF \\
\hline \multicolumn{7}{|l|}{ Demographic Characteristics } \\
\hline $\begin{array}{c}\text { Residency: } \\
\text { Urban } \\
\text { Rural }\end{array}$ & $\overline{1.19}$ & $\overline{0.84}$ & $\overline{1.24}$ & $\overline{0.81}$ & $\overline{1.24}$ & $\overline{0.81}$ \\
\hline Family size & 1.97 & 0.51 & 1.86 & 0.54 & 1.81 & 0.55 \\
\hline Age of $\mathrm{HH}$ & 2.38 & 0.42 & 2.02 & 0.50 & 2 & 0.50 \\
\hline $\begin{array}{l}\text { Gender: } \\
\text { Female } \\
\text { Male } \\
\end{array}$ & $\begin{array}{l}3.98 \\
- \\
\end{array}$ & $\begin{array}{l}0.25 \\
- \\
\end{array}$ & $\begin{array}{l}1.24 \\
- \\
\end{array}$ & $\begin{array}{l}0.81 \\
- \\
\end{array}$ & $\begin{array}{l}3.63 \\
- \\
\end{array}$ & $\begin{array}{l}0.28 \\
- \\
\end{array}$ \\
\hline $\begin{array}{c}\text { Marital status of } \mathbf{H H}: \\
\text { Never married } \\
\text { Married } \\
\text { Divorced } \\
\text { Widowed } \\
\end{array}$ & $\begin{array}{l}1.10 \\
- \\
1.19 \\
3.17\end{array}$ & $\begin{array}{l}0.91 \\
0.84 \\
0.32\end{array}$ & $\begin{array}{l}1.11 \\
- \\
1.14 \\
3.25\end{array}$ & $\begin{array}{l}0.90 \\
- \\
0.88 \\
0.31\end{array}$ & $\begin{array}{l}1.12 \\
- \\
1.13 \\
3.12 \\
\end{array}$ & $\begin{array}{l}0.89 \\
- \\
0.89 \\
0.32\end{array}$ \\
\hline \multicolumn{7}{|l|}{ Employment Status } \\
\hline $\begin{array}{l}\text { Employment of HH: } \\
\text { Unemployed } \\
\text { Employed } \\
\text { Pensioner }\end{array}$ & $\begin{array}{l}2.21 \\
6.62 \\
-\end{array}$ & $\begin{array}{l}0.45 \\
0.03 \\
-\end{array}$ & $\begin{array}{l}1.91 \\
9.96 \\
-\end{array}$ & $\begin{array}{l}0.52 \\
0.06 \\
-\end{array}$ & $\begin{array}{l}2.08 \\
10 \\
-\end{array}$ & $\begin{array}{l}0.48 \\
0.08 \\
-\end{array}$ \\
\hline $\begin{array}{l}\text { Employment of HH first spouse: } \\
\text { Unemployed } \\
\text { Employed } \\
\text { Pensioner }\end{array}$ & $\begin{array}{l}7.22 \\
7.07 \\
-\end{array}$ & $\begin{array}{l}0.14 \\
0.14 \\
-\end{array}$ & $\begin{array}{l}9.09 \\
9.85 \\
- \\
\end{array}$ & $\begin{array}{l}0.09 \\
0.09 \\
-\end{array}$ & $\begin{array}{l}9.47 \\
9.27 \\
-\end{array}$ & $\begin{array}{l}0.08 \\
0.09 \\
-\end{array}$ \\
\hline $\begin{array}{l}\text { Industry of employment of HH: } \\
\text { Agriculture } \\
\text { Commerce } \\
\text { Construction and electricity } \\
\text { Manufacturing } \\
\text { Public administration } \\
\text { Transportation } \\
\text { Services } \\
\text { Others }\end{array}$ & $\begin{array}{l}6.10 \\
2.43 \\
1.87 \\
1.73 \\
1.67 \\
- \\
1.58 \\
1.71\end{array}$ & $\begin{array}{l}0.28 \\
0.41 \\
0.53 \\
0.58 \\
0.60 \\
- \\
0.63 \\
0.58\end{array}$ & $\begin{array}{l}9.85 \\
3.83 \\
2.18 \\
2.08 \\
2.04 \\
- \\
1.68 \\
1.98\end{array}$ & $\begin{array}{l}0.06 \\
0.26 \\
0.46 \\
0.48 \\
0.49 \\
- \\
0.59 \\
0.51\end{array}$ & $\begin{array}{l}10.01 \\
3.59 \\
2.11 \\
2.16 \\
2.06 \\
- \\
1.63 \\
1.95\end{array}$ & $\begin{array}{l}0.09 \\
0.28 \\
0.48 \\
0.46 \\
0.49 \\
- \\
0.61 \\
0.51\end{array}$ \\
\hline $\begin{array}{l}\text { Sector of employment of } \mathbf{H H}: \\
\text { Public sector } \\
\text { Private sector } \\
\text { Others }\end{array}$ & $\begin{array}{l}1.11 \\
1.22 \\
- \\
\end{array}$ & $\begin{array}{l}0.89 \\
0.81 \\
- \\
\end{array}$ & $\begin{array}{l}3.69 \\
2.67 \\
-\end{array}$ & $\begin{array}{l}0.27 \\
0.37 \\
-\end{array}$ & $\begin{array}{l}3.18 \\
2.41 \\
- \\
\end{array}$ & $\begin{array}{l}0.31 \\
0.41 \\
- \\
\end{array}$ \\
\hline Number of earners & 1.84 & 0.54 & 1.71 & 0.59 & 1.76 & 0.57 \\
\hline Dependency ratio & 1.56 & 0.64 & 1.47 & 0.68 & 1.40 & 0.72 \\
\hline $\begin{array}{l}\text { Source of income: } \\
\text { Salaries and wages } \\
\text { Remittances } \\
\text { Household business } \\
\text { Others }\end{array}$ & $\begin{array}{l}- \\
1.02 \\
2.29 \\
1.41\end{array}$ & $\begin{array}{l}- \\
0.98 \\
0.43 \\
0.71\end{array}$ & $\begin{array}{l}- \\
1.03 \\
2.42 \\
1.50\end{array}$ & $\begin{array}{l}- \\
0.97 \\
0.41 \\
0.67\end{array}$ & $\begin{array}{l}- \\
1.04 \\
2.13 \\
1.46\end{array}$ & $\begin{array}{l}- \\
0.96 \\
0.47 \\
0.68\end{array}$ \\
\hline \multicolumn{7}{|l|}{ Health } \\
\hline Medical expenditures & 1.10 & 0.90 & 1.13 & 0.88 & 1.12 & 0.89 \\
\hline
\end{tabular}




\begin{tabular}{|l|l|l|l|l|l|l|}
\hline \multicolumn{1}{|l|}{ Education Status } \\
\hline Education level of HH: & 3.16 & 0.31 & 3.47 & 0.29 & 3.42 & 0.29 \\
$\quad$ Illiterate & 2.58 & 0.38 & 2.67 & 0.38 & 2.72 & 0.37 \\
Primary & 1.43 & 0.69 & 1.01 & 0.99 & 1.01 & 0.99 \\
Preparatory & 1.42 & 0.70 & 1.36 & 0.74 & 1.42 & 0.71 \\
Secondary \& post-secondary & 2.55 & 0.39 & 2.45 & 0.41 & 2.44 & 0.41 \\
Professional & - & - & - & - & - & 3.26 \\
University and above & 4.45 & 3.56 & & - \\
\hline Mean VIF & \multicolumn{7}{|l}{} \\
\hline
\end{tabular}

Table C-2: Breusch-Pagan/Cook-Weisberg Test for Heteroscedasticity

Ho: Constant variance

Variables: fitted values of natural log of consumption expenditures

\begin{tabular}{|l|l|}
\hline Year & Chi2 > Prob. \\
\hline 2015 & 0.841 \\
\hline 2013 & 0.326 \\
\hline 2011 & 0.137 \\
\hline
\end{tabular}




\section{Appendix D}

Table D-1: Simulation Analysis's Results in 2015

\begin{tabular}{|c|c|c|c|}
\hline \multicolumn{4}{|c|}{ 1- Family Size and Residency of Household } \\
\hline \multicolumn{2}{|c|}{ Rural } & \multicolumn{2}{|c|}{ Urban } \\
\hline Family Size & Probability of being poor $(\%)$ & Family Size & Probability of being poor $(\%)$ \\
\hline 1 & 4.19 & 1 & 2.12 \\
\hline 2 & 7.08 & 2 & 3.74 \\
\hline 3 & 11.46 & 3 & 6.38 \\
\hline 4 & 17.58 & 4 & 10.42 \\
\hline 5 & 25.43 & 5 & 16.17 \\
\hline 6 & 34.62 & 6 & 23.69 \\
\hline 7 & 44.42 & 7 & 32.66 \\
\hline 8 & 53.99 & 8 & 42.39 \\
\hline 9 & 62.67 & 9 & 52.08 \\
\hline 10 & 70.07 & 10 & 60.98 \\
\hline \multicolumn{4}{|c|}{ 2- Gender of $\mathrm{HH}$ and Residence } \\
\hline \multicolumn{2}{|c|}{ Rural } & \multicolumn{2}{|c|}{ Urban } \\
\hline Gender & Probability of being poor $(\%)$ & Gender & Probability of being poor $(\%)$ \\
\hline Female & 19.96 & Female & 13.28 \\
\hline Male & 25.84 & Male & 17.94 \\
\hline \multicolumn{4}{|c|}{ 3- Gender and Marital Status of $\mathrm{HH}$} \\
\hline \multicolumn{2}{|c|}{ Female } & \multicolumn{2}{|c|}{ Male } \\
\hline Marital Status & Probability of being poor $(\%)$ & Marital Status & Probability of being poor $(\%)$ \\
\hline Never married & 14.93 & Never married & 19.76 \\
\hline Married & 17.33 & Married & 22.59 \\
\hline Divorced & 24.30 & Divorced & 30.50 \\
\hline Widowed & 19.49 & Widowed & 25.10 \\
\hline \multicolumn{4}{|c|}{ 4- Working Status of $\mathrm{HH}$ and Spouse } \\
\hline \multicolumn{2}{|c|}{ Combination } & \multicolumn{2}{|c|}{ Probability of being poor $(\%)$} \\
\hline \multicolumn{2}{|c|}{$\begin{array}{l}\text { HH employment status: Employed } \\
\text { First spouse's employment status: Employed }\end{array}$} & \multicolumn{2}{|c|}{17.78} \\
\hline \multicolumn{2}{|c|}{$\begin{array}{l}\text { HH employment status: Employed } \\
\text { First spouse's employment status: Not-employed }\end{array}$} & \multicolumn{2}{|c|}{21.54} \\
\hline \multicolumn{2}{|c|}{$\begin{array}{l}\text { HH employment status: Not-employed } \\
\text { First spouse's employment status: Employed }\end{array}$} & \multicolumn{2}{|c|}{23.74} \\
\hline \multicolumn{2}{|c|}{$\begin{array}{l}\text { HH employment status: Employed } \\
\text { First spouse's employment status: Pensioner }\end{array}$} & \multicolumn{2}{|c|}{27.74} \\
\hline $\begin{array}{l}\text { HH employment status } \\
\text { First spouse's employn }\end{array}$ & $\begin{array}{l}\text { ployed } \\
\text { us: Pensioner }\end{array}$ & & \\
\hline $\begin{array}{l}\text { HH employment status } \\
\text { First spouse's employn }\end{array}$ & $\begin{array}{l}\text { er } \\
\text { us: Employed }\end{array}$ & & \\
\hline $\begin{array}{l}\text { HH employment status } \\
\text { First spouse's employn }\end{array}$ & $\begin{array}{l}\text { us: Not-employed } \\
\text { us: }\end{array}$ & & \\
\hline
\end{tabular}




\begin{tabular}{|c|c|c|c|}
\hline \multicolumn{2}{|c|}{$\begin{array}{l}\text { HH employment status: Pensioner } \\
\text { First spouse's employment status: Pensioner }\end{array}$} & \multicolumn{2}{|c|}{34.91} \\
\hline \multicolumn{2}{|c|}{$\begin{array}{l}\text { HH employment status: Not-employed } \\
\text { First spouse's employment status: Not-employed }\end{array}$} & \multicolumn{2}{|c|}{40.18} \\
\hline \multicolumn{4}{|c|}{ 5- HH Working Industry and Residency } \\
\hline \multicolumn{2}{|r|}{ Rural } & \multicolumn{2}{|r|}{ Urban } \\
\hline Industry & Probability of being poor $(\%)$ & Industry & Probability of being poor $(\%)$ \\
\hline Public administration & 20.28 & Public administration & 13.42 \\
\hline Manufacturing & 22.38 & Manufacturing & 15.05 \\
\hline Transportation & 23.79 & Transportation & 16.17 \\
\hline Services & 26.02 & Services & 17.96 \\
\hline Commerce & 26.80 & Commerce & 18.61 \\
\hline Construction & 28.47 & Construction & 19.99 \\
\hline Agriculture & 30.71 & Agriculture & 21.89 \\
\hline \multicolumn{4}{|c|}{ 6- Educational Level of $\mathrm{HH}$ and Residency } \\
\hline \multicolumn{2}{|r|}{ Rural } & \multicolumn{2}{|r|}{ Urban } \\
\hline Educational level & Probability of being poor $(\%)$ & Educational level & Probability of being poor $(\%)$ \\
\hline Illiterate & 38.09 & Illiterate & 28.22 \\
\hline Primary & 27.78 & Primary & 19.13 \\
\hline Preparatory & 24.09 & Preparatory & 16.12 \\
\hline Professional & 20.73 & Professional & 13.49 \\
\hline Secondary and Post-secondary & 14.98 & Secondary and Post-secondary & 9.26 \\
\hline University and above & 10.79 & University and above & 6.38 \\
\hline \multicolumn{4}{|c|}{ 7- Gender Educational Level of $\mathrm{HH}$} \\
\hline \multicolumn{2}{|r|}{ Female } & \multicolumn{2}{|r|}{ Male } \\
\hline Educational level & Probability of being poor $(\%)$ & Educational level & Probability of being poor $(\%)$ \\
\hline Illiterate & 27.97 & Illiterate & 34.86 \\
\hline Primary & 19.15 & Primary & 25.08 \\
\hline Preparatory & 16.22 & Preparatory & 21.67 \\
\hline Professional & 13.65 & Professional & 18.58 \\
\hline Secondary and Post-secondary & 9.48 & Secondary and Post-secondary & 13.37 \\
\hline University and above & 6.61 & University and above & 9.62 \\
\hline \multicolumn{4}{|c|}{ 8- Source of Income and Residency of Household } \\
\hline \multicolumn{2}{|r|}{ Rural } & \multicolumn{2}{|r|}{ Urban } \\
\hline Source of income & Probability of being poor $(\%)$ & Source of income & Probability of being poor $(\%)$ \\
\hline Salaries and wages & 26.75 & Salaries and wages & 18.73 \\
\hline Remittances & 26.58 & Remittances & 18.59 \\
\hline Household business & 21.13 & Household business & 14.21 \\
\hline
\end{tabular}

